\title{
Article
}

\section{Redox-Related Proteins in Melanoma Progression}

\author{
Larissa A. C. Carvalho ${ }^{1}$, Rodrigo G. Queijo ${ }^{1}{ }^{10}$, Alexandre L. B. Baccaro ${ }^{2}$, Ádamo D. D. Siena ${ }^{3}$, \\ Wilson A. Silva, Jr. ${ }^{3}{ }^{(0)}$, Tiago Rodrigues ${ }^{4}\left(\mathbb{D}\right.$ and Silvya Stuchi Maria-Engler ${ }^{1, *(1)}$
}

1 Department of Clinical and Toxicological Analysis, School of Pharmaceutical Sciences, University of São Paulo, Avenida Professor Lineu Prestes, 580, São Paulo 05508-00, SP, Brazil; lari.anastacio@gmail.com (L.A.C.C.); rodrigogoncalvesqueijo@usp.br (R.G.Q.)

2 Centro de Pós-Graduação e Pesquisa Oswaldo Cruz, Faculdade Oswaldo Cruz, Rua Brigadeiro Galvão, 535, Sao Paulo 01151-000, SP, Brazil; alexandre.baccaro@gmail.com

3 Department of Genetics, Ribeirão Preto Medical School, University of São Paulo, Avenida Bandeirantes, 3900, Ribeirao Preto 14049-900, SP, Brazil; adamo@usp.br (Á.D.D.S.); wilsonjr@usp.br (W.A.S.J.)

4 Center for Natural and Human Sciences, Federal University of ABC, Avenida dos Estados, 5001, Santo Andre 09210-580, SP, Brazil; trodrigues.ufabc@gmail.com

* Correspondence: silvya@usp.br

Citation: Carvalho, L.A.C.; Queijo, R.G.; Baccaro, A.L.B.; Siena, Á.D.D. Silva, W.A., Jr.; Rodrigues, T.; Maria-Engler, S.S. Redox-Related Proteins in Melanoma Progression. Antioxidants 2022, 11, 438. https:// doi.org/10.3390/antiox11030438

Academic Editor: Ana Luisa Kadekaro

Received: 11 January 2022

Accepted: 14 February 2022

Published: 22 February 2022

Publisher's Note: MDPI stays neutral with regard to jurisdictional claims in published maps and institutional affiliations.

Copyright: (c) 2022 by the authors Licensee MDPI, Basel, Switzerland. This article is an open access article distributed under the terms and conditions of the Creative Commons Attribution (CC BY) license (https:// creativecommons.org/licenses/by/ $4.0 /)$.

\begin{abstract}
Melanoma is the most aggressive type of skin cancer. Despite the available therapies, the minimum residual disease is still refractory. Reactive oxygen and nitrogen species (ROS and RNS) play a dual role in melanoma, where redox imbalance is involved from initiation to metastasis and resistance. Redox proteins modulate the disease by controlling ROS/RNS levels in immune response, proliferation, invasion, and relapse. Chemotherapeutics such as BRAF and MEK inhibitors promote oxidative stress, but high ROS/RNS amounts with a robust antioxidant system allow cells to be adaptive and cooperate to non-toxic levels. These proteins could act as biomarkers and possible targets. By understanding the complex mechanisms involved in adaptation and searching for new targets to make cells more susceptible to treatment, the disease might be overcome. Therefore, exploring the role of redox-sensitive proteins and the modulation of redox homeostasis may provide clues to new therapies. This study analyzes information obtained from a public cohort of melanoma patients about the expression of redox-generating and detoxifying proteins in melanoma during the disease stages, genetic alterations, and overall patient survival status. According to our analysis, $66 \%$ of the isoforms presented differential expression on melanoma progression: NOS2, SOD1, NOX4, PRX3, PXDN and GPX1 are increased during melanoma progression, while CAT, GPX3, TXNIP, and PRX2 are decreased. Besides, the stage of the disease could influence the result as well. The levels of PRX1, PRX5 and PRX6 can be increased or decreased depending on the stage. We showed that all analyzed isoforms presented some genetic alteration on the gene, most of them (78\%) for increased mRNA expression. Interestingly, 34\% of all melanoma patients showed genetic alterations on TRX1, most for decreased mRNA expression. Additionally, $15 \%$ of the isoforms showed a significant reduction in overall patient survival status for an altered group (PRX3, PRX5, TR2, and GR) and the unaltered group (NOX4). Although no such specific antioxidant therapy is approved for melanoma yet, inhibitors or mimetics of these redox-sensitive proteins have achieved very promising results. We foresee that forthcoming investigations on the modulation of these proteins will bring significant advances for cancer therapy.
\end{abstract}

Keywords: melanoma; resistance; redox proteins; oxidative stress; antioxidants

\section{Introduction}

Melanoma is one of the most aggressive tumors currently known [1]. More than 100,000 new cases afflicting both sexes were estimated in the US during 2020. It is the fifth most prevalent cancer in men and in women, corresponding to 7 and $5 \%$ of all estimated new cases of cancer. Its incidence increases, although it has begun to decline 
in recent birth cohorts [2]. Besides, a decline in yearly mortality has also been observed and might be ascribed to the higher survival of patients due to the new immunotherapy treatment with ipilimumab, the first immune checkpoint inhibitor approved for cancer therapy, and the targeted therapy with vemurafenib, a BRAF inhibitor (BRAFi) for the treatment of advanced melanoma approved by the Food and Drug Administration (FDA) in 2011. Still, the development of drug resistance is a significant clinical challenge to be overcome. The decline in mortality rate highlights the importance of investing in new cancer control interventions and in research to promote better treatment options [2]. Recent studies have suggested ROS/RNS increased production, oxidative stress, and the redox imbalance as the significant causes of melanomagenesis and melanoma resistance [3-6]. Thus, understanding these redox processes in melanoma development and resistance could help achieve better approaches for improved therapy.

The first event of melanoma is the formation of a benign nevus, which is the most pronounced proliferation of healthy melanocytes. This nevus is a uniformly colored lesion, with a regular pigmentation pattern in a circle and a tan or darkish-brown background. The nevus can become dysplastic, which is the anomalous development and is usually asymmetrical, with irregular edges containing various colors or increased diameters. A dysplastic nevus can evolve to radial growth, and cells proliferate intra-epidermically. Dysplastic nevus presenting elevated lesions already show intraepidermal cancer, and the cells can penetrate the dermis. In vertical growth, cells have the ability to invade the dermis, and form an expansive nodule, extending into the reticular dermis and fat. The last event is metastasis, in which cells successfully spread to other skin areas and other organs, proliferating, and establishing a metastatic focus [7].

In melanoma, ROS are generated as a consequence of (i) increased metabolism of transformed cells, (ii) immune response against the tumor, (iii) UV irradiation, (iv) melanin production, and $(\mathrm{v})$ an altered antioxidant system [8,9]. Vemurafenib itself promoted mitochondrial fusion in melanoma cells [10] and increased oxidative metabolism and ROS production [11]. The FDA also approved the use of combined BRAF and MEK inhibitors, which have doubled the time of progression, but also leads to relapse. In fact, resistance to BRAF and MEK inhibitors is related to the oxidative metabolism [12-14]. It has been suggested to induce oxidative stress to make resistant cells more vulnerable [15]. Still, disruption of redox balance enhances the effects of BRAF-inhibition in melanoma [16]. In this sense, overcoming targeted therapy resistance is a major concern in melanoma field.

The higher amounts of ROS/RNS generated by cancer cells subsidize the molecular changes that drive tumor initiation, promotion, progression, and chemoresistance [17]. Reactive species act as signaling mechanisms for proliferation, vascular function, and wound healing at physiological levels. Lower levels enable cell cycle arrest, while higher levels can drive cells to death [17].

Tumor-promoting functions of ROS/RNS comprise (i) tumorigenesis: according to the concentration and duration of exposure, ROS can drive genomic instability, act downstream to the activation of oncogenes or inactivation of tumor suppressor genes, modulate activities of signaling pathways involved in tumor proliferation (PI3K and MAPK) and they also may induce epigenetic alterations by methylating and inactivating tumor suppressor genes; (ii) angiogenesis: ROS can affect angiogenesis by mediating endothelial cell proliferation, migration, and tube formation, and they also modulate VEGF signaling; (iii) invasion and metastasis: subtle increases in steady-state $\mathrm{H}_{2} \mathrm{O}_{2}$ levels can lead to pro-migratory signaling in cancer, endogenous growth factors, and cytokines which are known to display critical functions in the invasiveness (some mediating ROS generation ROS). ROS also participate in cell migration by modulating the actin cytoskeleton. It can oxidize/inhibit phosphotyrosine phosphatase (PTP) and prevent the enzyme from dephosphorylating and inactivating FAK (involved in controlling cell motility). Additionally, it is involved in the redox-dependent degradation of extracellular matrix by several mechanisms; (iv) chemoresistance: ROS could modulate critical proteins involved in therapy resistance [17]. In addition, redox switches can lead the transformation status of quiescent to proliferative 
cells [18]. ROS/RNS may contribute to aggressiveness, self-renew, antiproteases inhibition, local tissue injuring and tumor heterogeneity promotion $[19,20]$. Consequently, more aggressive cancer cells, such as melanoma cells, have higher levels of ROS than normal healthy cells $[5,19]$.

However, ROS/RNS can also act as a tumor-suppressor agent. Although higher amounts of ROS/RNS could be beneficial to tumorigenesis and resistance, the augmented antioxidant defense in these cells indicates that decreasing antioxidant defense and increasing ROS/RNS levels further to a toxic level may push cells beyond the breaking point, suppressing tumor development and providing a unique opportunity to eliminate the tumor. This could be accomplished by using drugs that increase ROS production, inhibit the antioxidant defense, or a combination of both [17]. In this sense, ROS/RNS can activate several cell-death pathways, so several agents were reported to effectively eradicate and sensitize cancer cells to chemotherapeutic agents via modulating ROS/RNS production. It is well accepted that ROS/RNS can eliminate tumor cells via apoptosis, autophagy, necroptosis, and ferroptosis (a novel type of non-apoptotic, non-autophagic, and non-necroptotic form of cell death) $[17,19,21,22]$.

In this line, decreasing ROS/RNS levels or using antioxidants could also be considered a promising alternative to prevent ROS-mediated tumor development. Enzymatic and non-enzymatic components form the antioxidant defense system. Non-enzymatic antioxidants comprise carotenoids, ascorbic acid, vitamin $\mathrm{D}$ derivatives, flavonoids, $\mathrm{N}$-acetyl cysteine (NAC), $\alpha$-tocopherol, and other small molecules. Conversely, enzymatic antioxidants are redox-sensitive proteins, like superoxide dismutase (SOD), peroxiredoxin (PRX), thioredoxin system (TRX), glutathione peroxidase (GPX), glutathione reductase (GR), and catalase (CAT) $[11,19,20,23]$.

In view of the aspects mentioned above, the exact role of ROS/RNS in cancer is still contradictory and context-dependent. Once ROS/RNS and antioxidants can promote or suppress tumors, new therapies that induce or inhibit such species may present advantages and disadvantages [17]. A better understanding of the mechanisms involved in these treatments may allow the development of new promising strategies. Besides, understanding the redox balance involved in cancer is still a challenge.

\section{Materials and Methods}

In order to analyze the expression of genes in melanoma progression, public microarray data initially published by Scatolini et al. (2010) [24] was used. In this data set, there are samples from 18 common nevi, 11 dysplastic nevi, 8 from a radial phase of melanoma growth, 15 from vertical phase of melanoma growth and 5 from melanoma metastases. These data were downloaded from the Gene Expression Omnibus-GEO repository (https: / / www.ncbi.nlm.nih.gov/geo/ accessed on 10 September 2019), under the code GSE12391. The statistical analysis corresponds to the Analysis of Variance (ANOVA) followed by the Tukey post-hoc test. All analyzed data and the images generated were obtained using the R platform and Prism GraphPad 7 software. For the patient's data analysis, we chose to keep the sample classifications as already mentioned by the reference paper and investigate gene expression at different stages of the disease, i.e., benign nevus, dysplastic nevus, radial growth, vertical growth, and metastatic melanoma. Such classification is interesting since it provides insights into the role of the genes during the disease progression, and they can be used as biomarkers. To analyze the genetic alterations and overall patient survival status in cutaneous skin melanoma, the cBioPortal for Cancer Genomics was used. The cBioPortal for Cancer genomics is an open-access resource: http://www.cbioportal.org/ accessed on 28 June 2021 [25,26]. The name of the genes was searched in the cBioPortal database for skin cutaneous melanoma (TCGA, Firehose Legacy), $n=479$ samples. The selected genomic profiles were mRNA expression and protein expression with a z-score threshold of 1.5 . 


\section{Results}

\subsection{RNS and ROS-Generating Enzymes}

3.1.1. Nitric Oxide Synthase (NOS)

Nitric oxide (NO) is a free radical that participates in melanoma signaling. Elevated NO levels correlate with poor outcomes, but intermediate levels can limit tumor cell proliferation. Therefore, the synthesis of NO by nitric oxide synthase (NOS) plays an essential role in melanoma progression [27]. NOS catalyzes the reaction of L-arginine and oxygen with NADPH as co-substrate to produce L-citrulline and NO. Humans express three isoforms of NOS, namely neuronal NOS (nNOS or NOS1), inducible NOS (iNOS or NOS2), and endothelial NOS (eNOS or NOS3). The eNOS and nNOS isoforms are grouped as constitutively active NOS (cNOS), while iNOS is induced by immunologic stimuli $[28,29]$. Normal melanocytes express both cNOS and iNOS [30].

Current literature proposes that NO displays a controversial role in melanoma by inducing or inhibiting apoptosis, with both pro- and anti-tumorigenic activities (reviewed in 27). It was shown that NOS activity and levels are significantly higher in melanoma than in melanocytes [31-33]. Previous studies indicated that iNOS promoted tumor proliferation [34-36], and it was associated with poor patient survival and increased resistance to cisplatin [37]. It was found that nNOS was expressed in $49 \%$ of benign nevi, $72 \%$ of atypical nevi, and $82 \%$ of primary malignant cells, suggesting its role in melanoma progression [38]. Thus, nNOS is increased in melanoma and is associated with a more proliferative profile $[39,40]$, possibly contributing to cell escape from apoptosis [40]. The eNOS could be involved in melanoma development, since its uncoupling is an important source of superoxide that drives the malignant transformation [41].

Specific nNOS and iNOS inhibitors exhibited promising efficacy against both in vitro and pre-clinical melanoma mouse models [39,42-44], and reduced proliferation of melanoma cells [39,43-45]. The use of extracellular NO donor or intracellular expression of iNOS revealed that NO exposure supports growth/survival in melanoma [46]. On the other hand, inducing iNOS with evodiamine increases NO production and drives apoptosis [47]. Once there are still some contradictory data about the pro- or anti-tumorigenic effects of NO inhibition, probably due to the several levels that it can achieve, further studies should be accomplished to clarify its real role in melanoma.

Furthermore, our data analysis showed that $14 \%$ of the melanoma patients have genetic alteration on NOS1 gene, $8 \%$ on NOS2 and $18 \%$ on NOS3. Higher mRNA was the most prevalent alteration of NOS2 and NOS3, while missense mutation was more prevalent for NOS1 (Figure 1A). However, none of these isoforms caused significative change in patient survival (Figure 1B). Our data from patient biopsies, showed that there were no significant alterations in the NOS1 and NOS3 expression levels during melanoma progression (Figure 1C). However, the expression of NOS2 was significantly increased in the vertical growth phase when compared to dysplastic nevus and in metastatic melanoma once compared to the common and dysplastic nevus (Figure 1C).

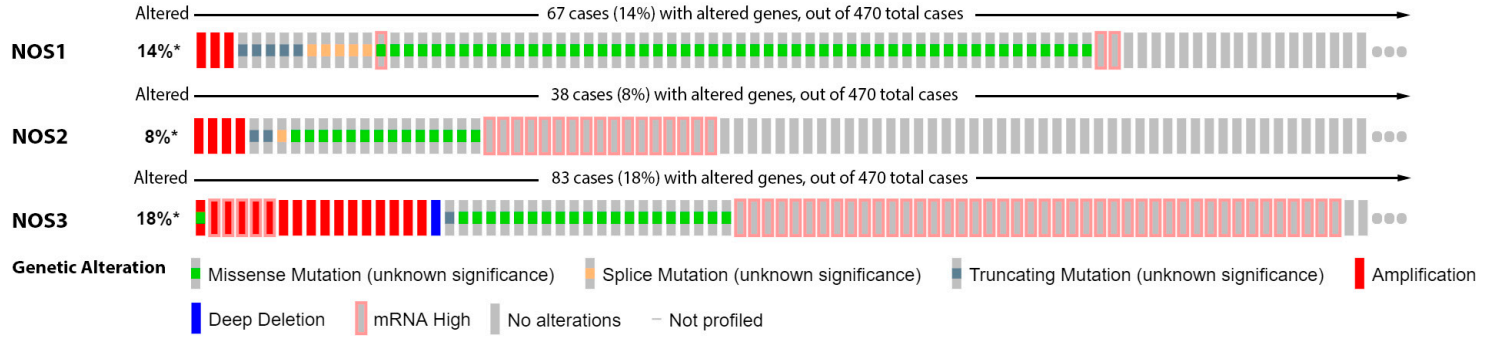

Figure 1. Cont. 

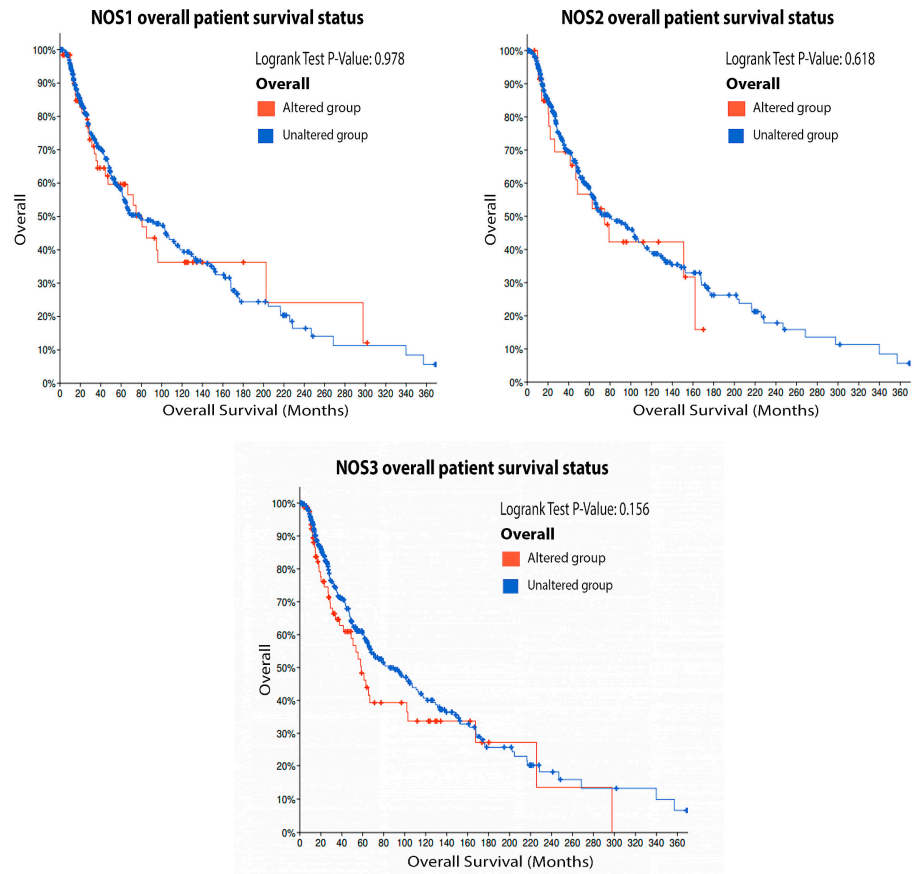

(B)
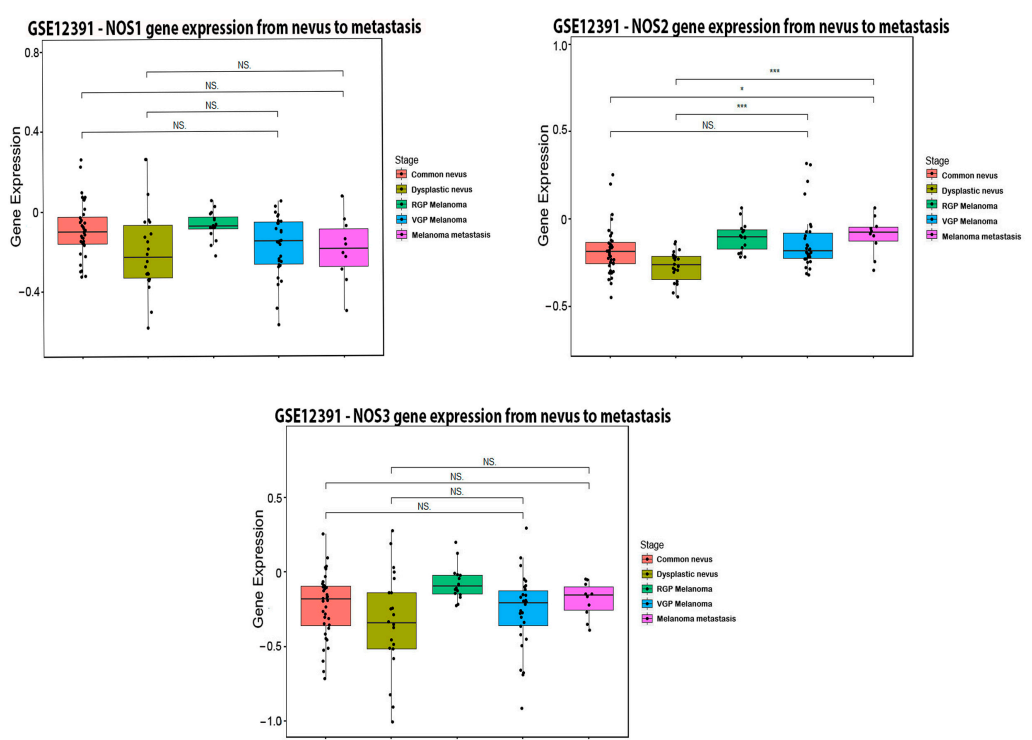

(C)

Figure 1. Nitric oxide synthase on melanoma. (A) Percentage of patients with altered genes and types of genetic alterations; (B) overall patient survival status, and (C) expression in melanoma progression. Red boxes represent the common nevus, yellow boxes the dysplastic nevus, green boxes the radial growth phase (RGP) melanoma, blue boxes the vertical growth phase (VGP) melanoma, and purple boxes the metastatic melanoma. The statistical analysis was performed by ANOVA followed by Tukey test, with ${ }^{* * *} p<0.001,{ }^{*} p<0.05$ when compared to common or dysplastic nevus. NS: Not significant.

\subsubsection{NADPH Oxidase (NOX)}

The NADPH oxidase (NOX) family comprises a class of flavoenzymes that uses one or two electrons of NADPH to reduce oxygen to superoxide radical $\left(\mathrm{O}_{2}{ }^{\bullet-}\right)$ and $\mathrm{H}_{2} \mathrm{O}_{2}$, across biological membranes. There are seven NOX isoforms in mammals, i.e., NOX1-NOX5, and the dual oxidases DUOX-1 and DUOX-2 [48]. NOX4, DUOX- 1 and DUOX-2 produce $\mathrm{H}_{2} \mathrm{O}_{2}$, while NOX1-3 and NOX5 produce $\mathrm{O}_{2}{ }^{\bullet-}$ [49]. Among the NOX family, NOX1 and NOX4 
isoforms play a major role in melanoma, while NOX5 is also important but still scarcely studied [50].

The expression and activity of NOX1 are increased in melanoma cells and their stages $[19,51]$. Its overexpression increases melanoma invasiveness, while the knockdown or inhibition decreases it. Indeed, NOX1 seems to be involved in epithelial-mesenchymal transition (EMT) [51]. NOX4 expression is increased in several melanoma cell lines. It is associated with metastasis, and its silencing decreases cell growth and tumorigenicity in nude mice. The use of DPI and antioxidants blocked melanoma cell proliferation, and the knockdown of NOX4 induced G2-M cell cycle arrest [52]. Pharmacological NOX inhibition and its silencing decreased the viability of the human melanoma cell line, and induced cellular shape changes by disassembling focal adhesion processes through the FAK pathway [53]. NOX5 is overexpressed in melanoma [50]. Its overexpression in UACC257 melanoma cells increases cell growth, BrdU positive cells, $\gamma$-H2AX levels, normoxic HIF- $1 \alpha$ expression, and decreased p27Kip1 expression. In contrast, the knockdown of NOX5 decreases cell growth, HIF-1 $\alpha$ expression, Akt and GSK3 $\beta$ phosphorylation, and increases p27Kip1 expression. Therefore, the expression of NOX5 supports cell proliferation by generating ROS that modulates HIF- $1 \alpha$ and AKT/GSk3 $\beta /$ p27Kip1 [54]. Once it was revealed that NOX enzymes played a critical role in melanoma, they were used as a targeted therapy $[19,55,56]$. There are several NOX inhibitors that hold great potential against melanoma. The inhibition of NOX with DPI decreased ROS production, inhibited cell growth, promoted cell differentiation of B16 melanoma cells, and increased MITF expression [57].

In this regard, we showed that $13 \%$ of the melanoma patients have alterations on NOX1 gene, $7 \%$ on NOX2, NOX3 and NOX5, and $15 \%$ on NOX4. The most prevalent genetic alterations were increased mRNA expression for NOX1-4 and missense mutation for NOX5 (Figure 2A). Only the altered group of patients with mutations on NOX4 demonstrated significative increased survival (Figure 2B). Our data analysis points out to the lower NOX1 expression in VGP melanoma than in common nevus (Figure 2C), while no significant differences were found for NOX3 and NOX5 at different stages (Figure 2C). Moreover, NOX2 and NOX4 expression was increased during melanoma progression (Figure 2C).

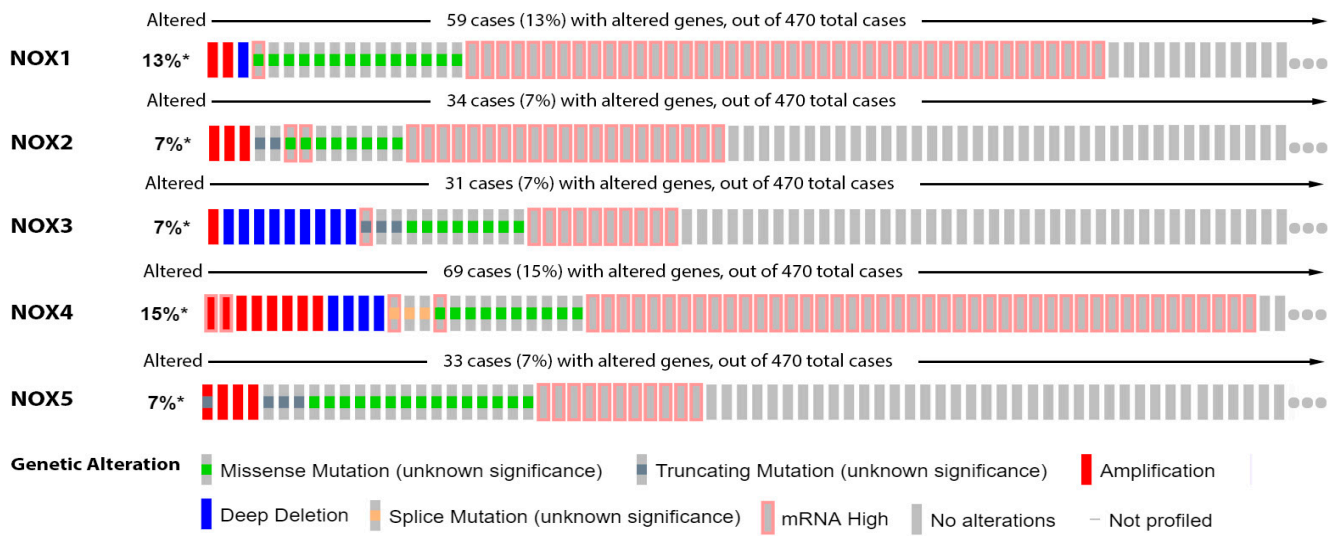

(A)

Figure 2. Cont. 

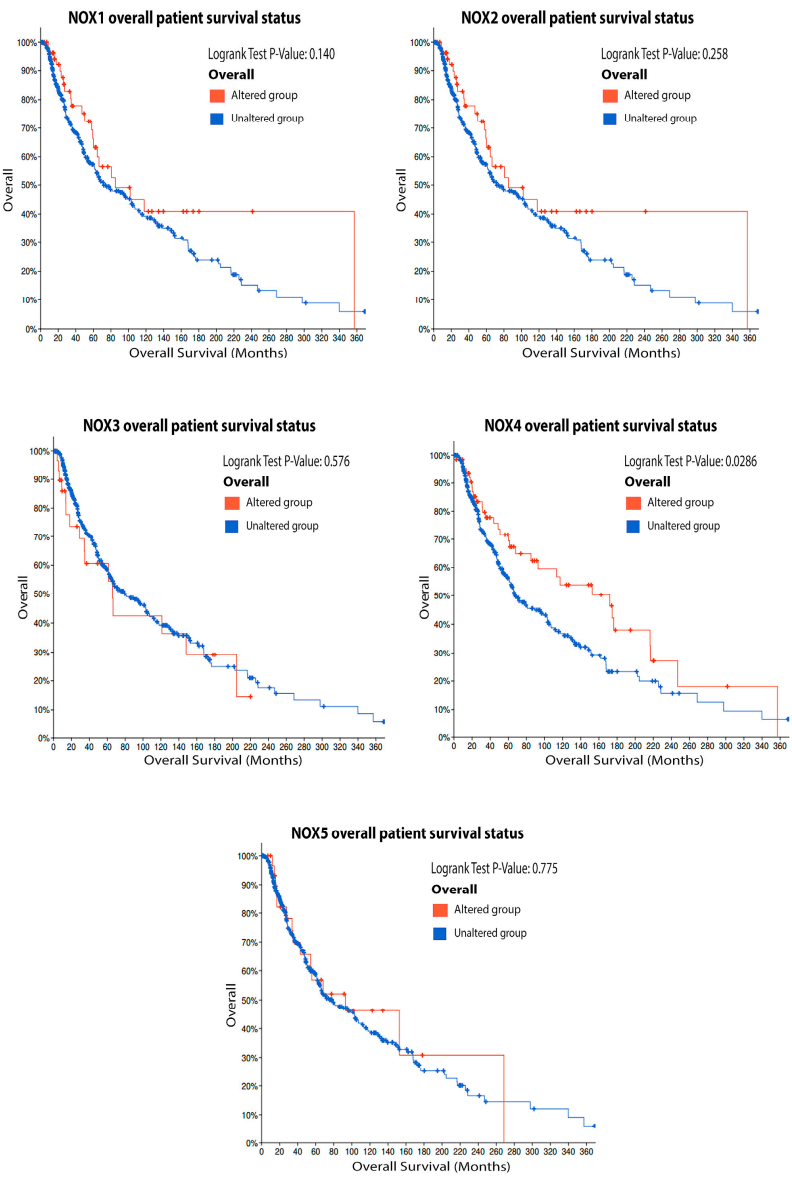

(B)
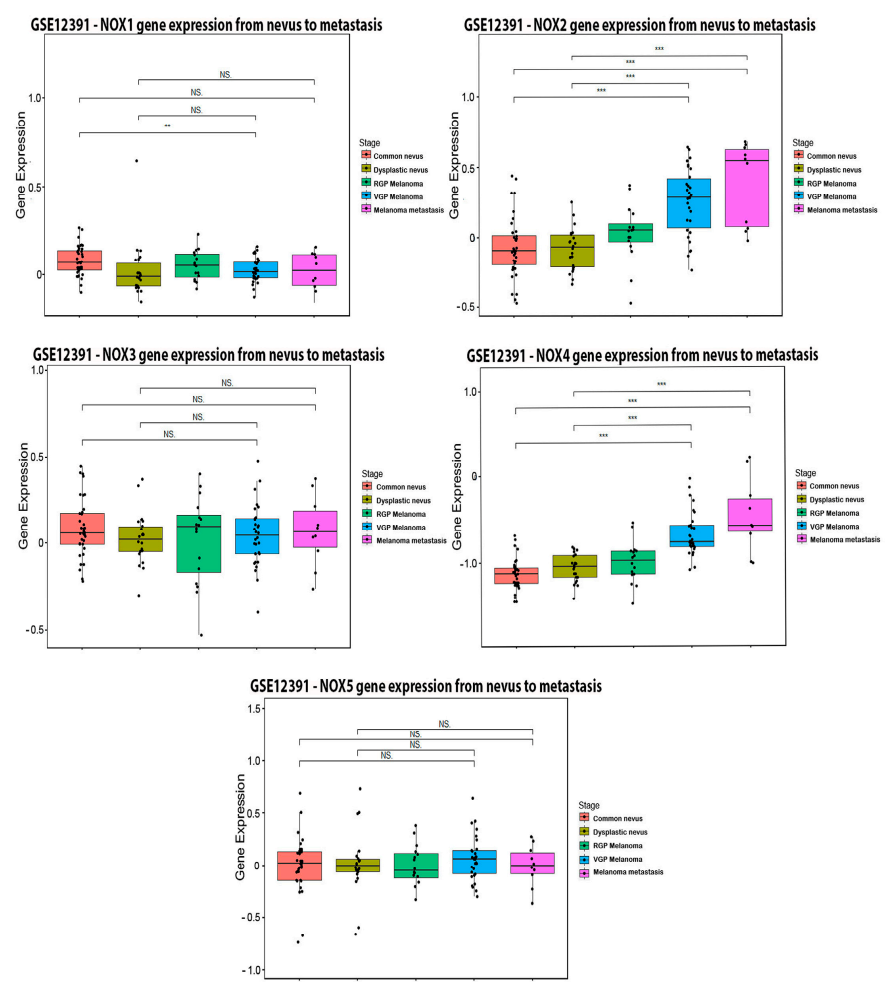

(C)

Figure 2. NADPH oxidases on melanoma. (A) Percentage of patients with altered genes and types of 
genetic alterations; (B) overall patient survival status, and (C) expression in melanoma progression. Red boxes represent the common nevus, yellow boxes the dysplastic nevus, green boxes the radial growth phase (RGP) melanoma, blue boxes the vertical growth phase (VGP) melanoma, and purple boxes the metastatic melanoma. The statistical analysis was performed by ANOVA followed by Tukey test, ${ }^{* * *} p<0.001,{ }^{* *} p<0.01,{ }^{*} p<0.05$ when compared to common or dysplastic nevus. NS: Not significant.

\subsection{RNS and ROS-Detoxifying and Sensitive Enzymes}

\subsubsection{Superoxide Dismutase (SOD)}

Superoxide dismutases are enzymes that catalyze the dismutation reaction to convert $\mathrm{O}_{2}{ }^{\bullet-}$ into $\mathrm{H}_{2} \mathrm{O}_{2}$. There are three described SOD isoforms, i.e., SOD1 (CuZnSOD) located in the cytoplasm, SOD2 (MnSOD) in the mitochondria, and SOD3 (ecSOD) in the extracellular compartment [58].

Several studies proposed that SOD2 activity or expression is altered in skin cancers, although its role is still controversial in melanoma. It was shown that lower levels of SOD2 is related to metastasis [59]. Besides, an increased expression of SOD2 suppressed the malignant phenotype of melanoma cells in vitro, and also led to the loss of the colonyforming ability [60]. In contrast, Schadendorf showed that serum SOD2 level was elevated in melanoma patients and, since it was correlated to the disease progression, they proposed SOD2 as a tumor marker and a sensitive biomarker in serum for monitoring melanoma [61]. The alterations in SOD expression are involved in therapy resistance as well [62]. Though few studies are addressing the role of SOD1 and SOD3 in melanoma, it was shown that SOD1 is involved in melanogenesis and/or differentiation $[63,64]$. The overexpression of SOD3 inhibited the growth of B16F1 melanoma cells [65]. Considering that ROS are involved in cellular proliferation signaling, antioxidant therapies using SOD mimetics are currently being explored [66]. However, it is also important to consider that depending on the ROS levels; it might help the tumor progression.

From our data analysis, $14 \%$ of the melanoma patients showed alteration on the SOD1 gene, $7 \%$ on SOD2, and $4 \%$ on SOD3. The most prevalent mutation was increased mRNA expression (Figure 3A). None of the isoforms had a significant impact on patient survival (Figure 3B). SOD1 expression increases from a common nevus and dysplastic nevus to melanoma vertical growth phase (Figure 3C), while SOD2 has no significant difference (Figure $3 \mathrm{C}$ ). Moreover, we found that SOD3 was downregulated in melanoma when compared to nevus (Figure 3C).

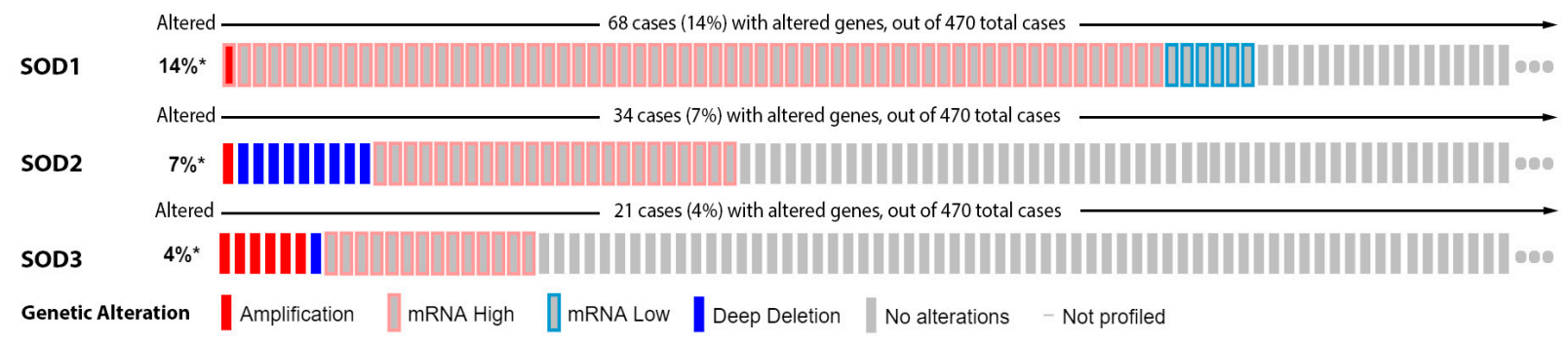

(A)

Figure 3. Cont. 

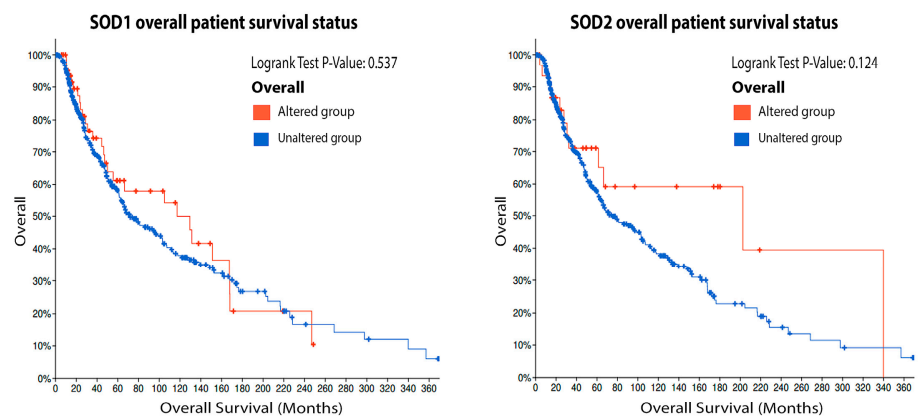

SOD3 overall patient survival status

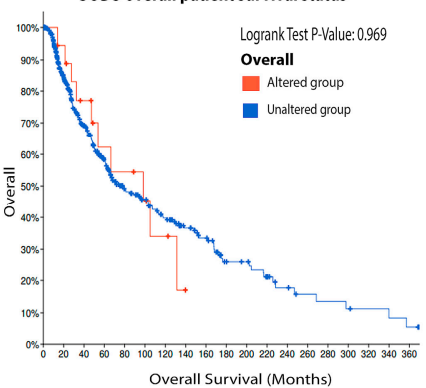

(B)

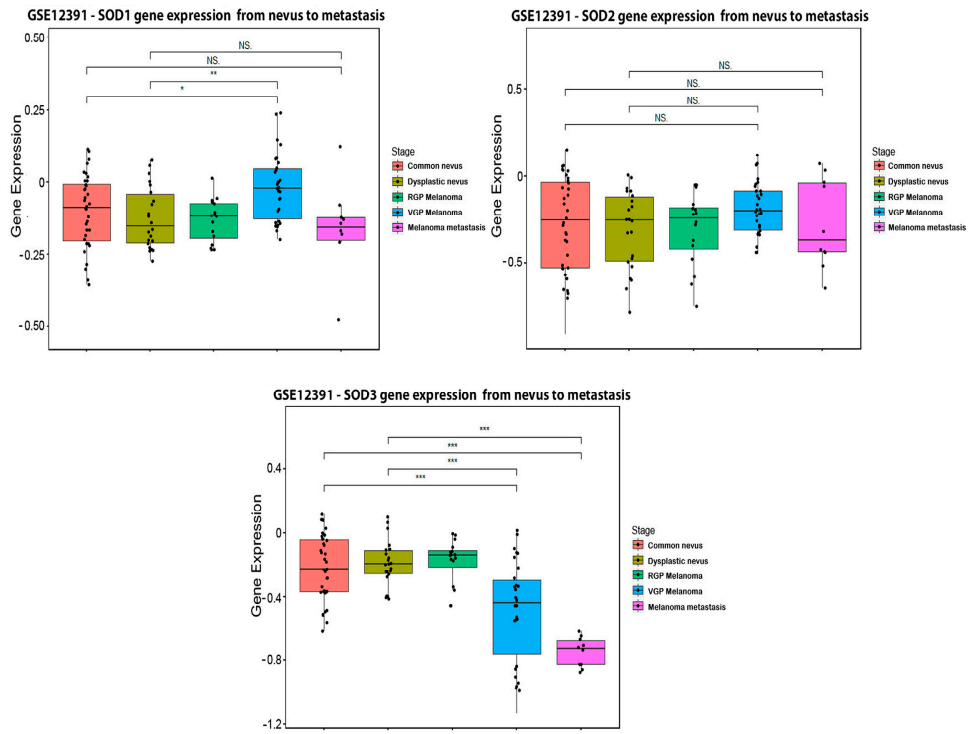

(C)

Figure 3. Superoxide dismutase on melanoma. (A) Percentage of patients with altered genes and types of genetic alterations; (B) overall patient survival status, and (C) expression in melanoma progression. Red boxes are common nevus, yellow boxes are dysplastic nevus, green boxes are radial growth phase (RGP) melanoma, blue boxes are vertical growth phase (VGP) melanoma, and purple boxes are metastatic melanoma. The statistical analysis was performed by ANOVA followed by Tukey test, ${ }^{* * *} p<0.001,{ }^{* *} p<0.01,{ }^{*} p<0.05$ when compared to common or dysplastic nevus. NS: Not significant.

\subsubsection{Catalase (CAT)}

Catalase is a peroxidase-type enzyme that converts two $\mathrm{H}_{2} \mathrm{O}_{2}$ to $\mathrm{O}_{2}$ and $\mathrm{H}_{2} \mathrm{O}$. Healthy melanocytes from melanoma patients exhibited decreased catalase activity and increased SOD activity, suggesting a redox imbalance during the melanoma progression [67]. Compared to CHO cells, melanoma cells presented decreased activities of catalase and SOD [68]. Moreover, another study proposed that catalase activity was increased in stages I, II, and III, 
but not in stage IV [69], evidencing a protective role of catalase in metastasis. A microarray in melanoma cells with different ROS levels after overexpression of catalase showed that dissimilar phenotypes were generated by differential compensation to hydrogen peroxide scavenging. These gene signatures were shown to promote melanogenesis or resemble less aggressive tumor cells by improving the antioxidant system, demonstrating that redox imbalance could control non-aggressive and metastatic melanomas [70].

Once catalase was shown to play a crucial role in melanoma, some studies using the cell-permeant polyethylene glycol conjugated catalase (PEG-catalase) have been published. It was shown that PEG-catalase inhibited cell survival, adhesion, invasion, and proliferation due to the induction of tumor dormancy [71]. The use of PEG-catalase prevented ROSinduced metastasis after surgical removal [71]. When melanoma cells were injected in mice and the animals were treated with PEG-catalase intravenously, almost a complete suppression of the growth of metastatic tumor in the lung was observed [72]. In this sense, despite some redox imbalance controversy of catalase, the use of PEG-catalase seems a promising therapy for melanoma.

Our analysis demonstrated that $10 \%$ of the melanoma patients have the mutation on the CAT gene and the most common was increased mRNA expression (Figure 4A). These mutations had no significant impact on survival (Figure 4B). Compared to dysplastic nevus, our data (Figure 4C) shows that catalase expression decreased through the vertical growth phase and metastatic melanoma.

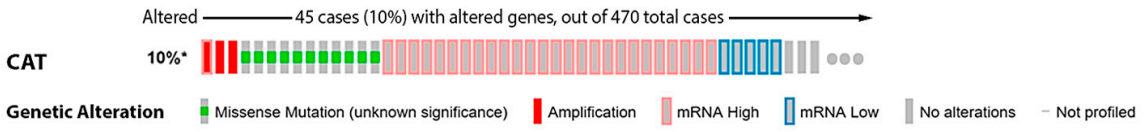

(A)

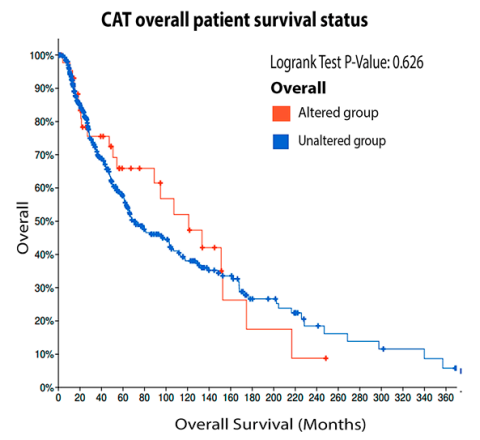

(B)

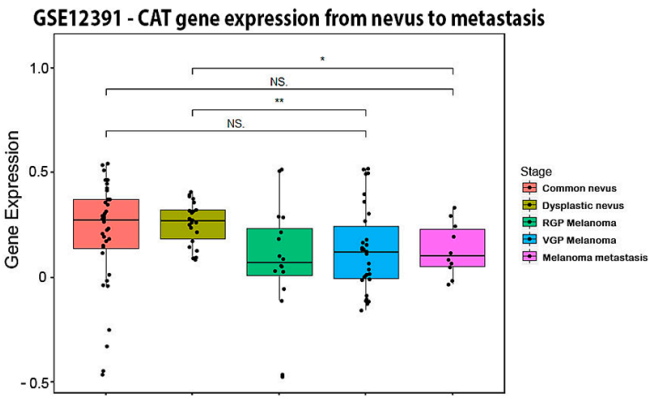

(C)

Figure 4. Catalase on melanoma. (A) Percentage of patients with altered genes and types of genetic alterations; (B) overall patient survival status, and (C) expression in melanoma progression. Red boxes represent the common nevus, yellow boxes the dysplastic nevus, green boxes the radial growth phase (RGP) melanoma, blue boxes the vertical growth phase (VGP) melanoma, and purple boxes the metastatic melanoma. The statistical analysis was performed by ANOVA followed by Tukey test, ${ }^{* *} p<0.01,{ }^{*} p<0.05$ when compared to common or dysplastic nevus. NS: Not significant. 


\subsubsection{Glutathione System}

Glutathione ( $\gamma$-L-glutamyl-L-cysteinyl-glycine) is a tripeptide that can assume two redox conditions: reduced form (GSH) or oxidized disulfide form (GSSG). It is a key antioxidant against $\mathrm{ROS}, \mathrm{RNS}$, hypochlorous acid $(\mathrm{HOCl})$, hydroxyl radicals $(\mathrm{HO} \bullet)$, and other reactive oxidative species. It can act altogether with glutathione peroxidase (GPX), glutathione S-transferase (GST) and glutaredoxin (GLRX). GPX is responsible for the detoxification of organic and inorganic peroxides. Its activity depends on GSH, which is oxidized to GSSG. GST catalyzes the conjugation of GSH to a variety of endogenous and exogenous electrophilic compounds. They are divided into eight classes based on sequence homology: alpha (GSTA), theta (GSTT), mu (GSTM), omega (GSTO), kappa (GSTK), zeta (GSTZ), sigma (GSTS), and pi (GSTP). Glutaredoxins are small cytosolic enzymes, which reverse glutathione adducts on protein thiols. In all cases, the GSSG can be reduced by another enzyme called glutathione reductase (GR) using electrons from NADPH [73].

GSH is important to support redox homeostasis during melanin biosynthesis at the melanocytes [73]. A high GSH/GSSG ratio has an important role in metastatic progression [74-76]. Normal skin seems to have low redox capacity, whilst drug-sensitive melanoma cells have moderate redox capacity, and drug-resistant has high redox [16]. It has been demonstrated that melanoma cells are resistant to oxidative stress by maintaining elevated GSH, SOD, CAT and GPX levels [77,78]. Metastatic cells might consume GSH to keep redox homeostasis, once the GSH/GSSG ratio is lower in metastatic melanoma cells. Besides, it was shown that antioxidant therapy could promote invasion $[76,79]$. GSH promotes cell growth and resistance to therapy. Therefore, GSH depletion decreased the number and volume of invasive cells, and sensitizes melanoma to combination therapy [80]. It is well accepted that cells with decreased sensitivity to BRAFi present higher levels of antioxidant metabolites NADPH and GSH [16]. In fact, resistant cells adapt to oxidative stress by increasing GSH levels [13] and, in this context, drugs that oxidize or reduce GSH levels are under evaluation in clinical trials, in order to improve targeted therapy efficacy [81]. L-Buthionine-S-sulfoximine (BSO) is a selective and irreversible inhibitor of the enzyme $\gamma$-glutamylcysteine synthetase ( $\gamma$-GCS) involved in the first step of GSH synthesis. Its use is associated with GSH depletion, and increased oxidative stress [82,83]. Additionally, BSO can downregulate GST expression, inhibit cell proliferation [72,84] and could also help to overcome melanoma resistance [85]. The depletion of GSH induced oxidative stress and apoptosis in melanoma cells [86].

GPX1 expression is augmented in melanoma. It is related to increased proliferation, and its depletion leads to a reduction of cellular growth [87]. GPX3 is considered an antioxidant protein and a possible tumor suppressor gene. It is downregulated in several tumors, including melanoma. Decreased levels of GPX3 are related to increased proliferation, motility, invasiveness, and poor prognosis [88]. Overexpression of GPX3 decreased the viability of melanoma cells and inhibited their growth in a xenografts model [89]. This data points to the important role of GPX3 inhibiting melanoma progression, and this subject should be more addressed in the field. Compared to the primary tumor, GST levels are decreased in metastasis derived from skin or lymph nodes. However, GST was increased with tumor progression, and GST $\pi$ was the most expressed [90]. Its activity is correlated to malignity [91], and it is directly involved in melanoma invasion [92]. GSTs are related to the development of drug resistance in melanoma [93]. On the other hand, the isozymes GSTT and GSTM are absent in a large proportion of the population. They may affect the development of melanoma by decreasing oxidative stress [94]. GLRX is involved in angiogenesis and resistance [73,85,95-98]. The increased tumor progression in diabetes mellitus may be associated with GLRX upregulation [99]. GR is less studied, although it also seems to be relevant. The inhibition of GR generates oxidative stress and suppresses lung metastasis and subcutaneous growth of melanoma in vivo, and also decreases proliferation, colony formation, cell adhesion, migration, invasion in melanoma cells in vitro, blocks epithelial-to-mesenchymal transition (EMT) and affects actin rearrangement. In this 
sense, GR could act as a regulator of oxidative stress, and a potential target for melanoma therapy [100].

It is possible to observe in our data analysis, presented in the Figure 5 , that $6 \%$ of the patients have alteration on the GPX1 gene, $5 \%$ on GPX3, 10\% on GSTM1, 13\% on GSTP1, $10 \%$ on GSTT1, 5\% on GLRX1, and 15\% on GR. The most prevalent alteration was increased mRNA expression, except for GR that showed decreased mRNA expression (Figure 5A). Only GR alteration on patients had a significative decrease in survival (Figure 5B). Glutathione-related enzymes are differentially expressed in melanoma progression. GPX1 is increased in VGP melanoma compared to common nevus (Figure 5C). GPX3 is decreased in metastasis (Figure 5C). GSTM1 is not altered (Figure 5C). GSTP1 is decreased in metastasis compared to common and dysplastic nevus (Figure 5C). GSTT1 is decreased in VGP and metastatic melanoma compared to common and dysplastic nevus (Figure 5C). GLRX is decreased in metastatic melanoma compared to dysplastic nevus (Figure 5C). GR is increased in metastasis compared to common and dysplastic nevus (Figure 5C).

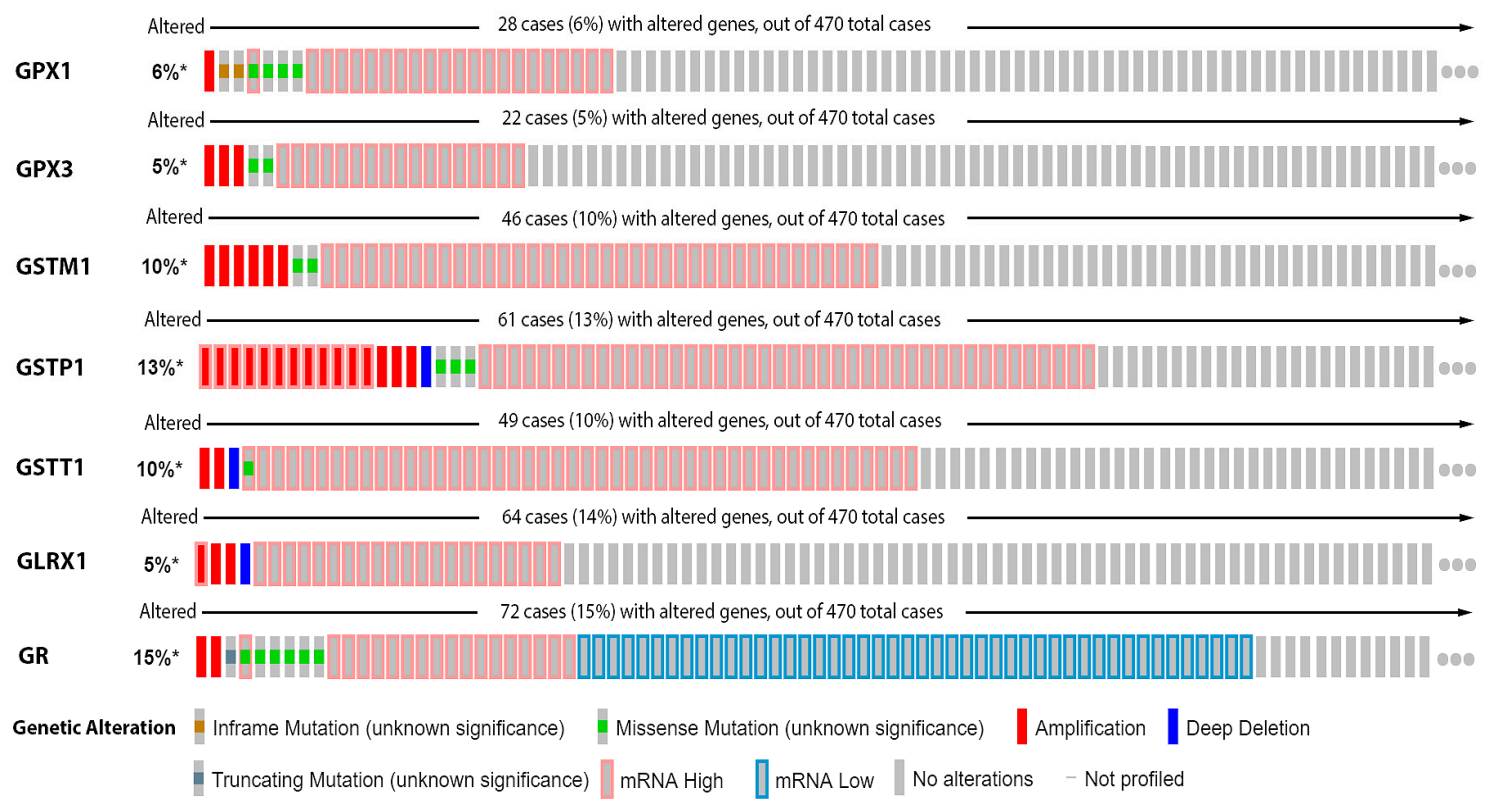

(A)

Figure 5. Cont. 

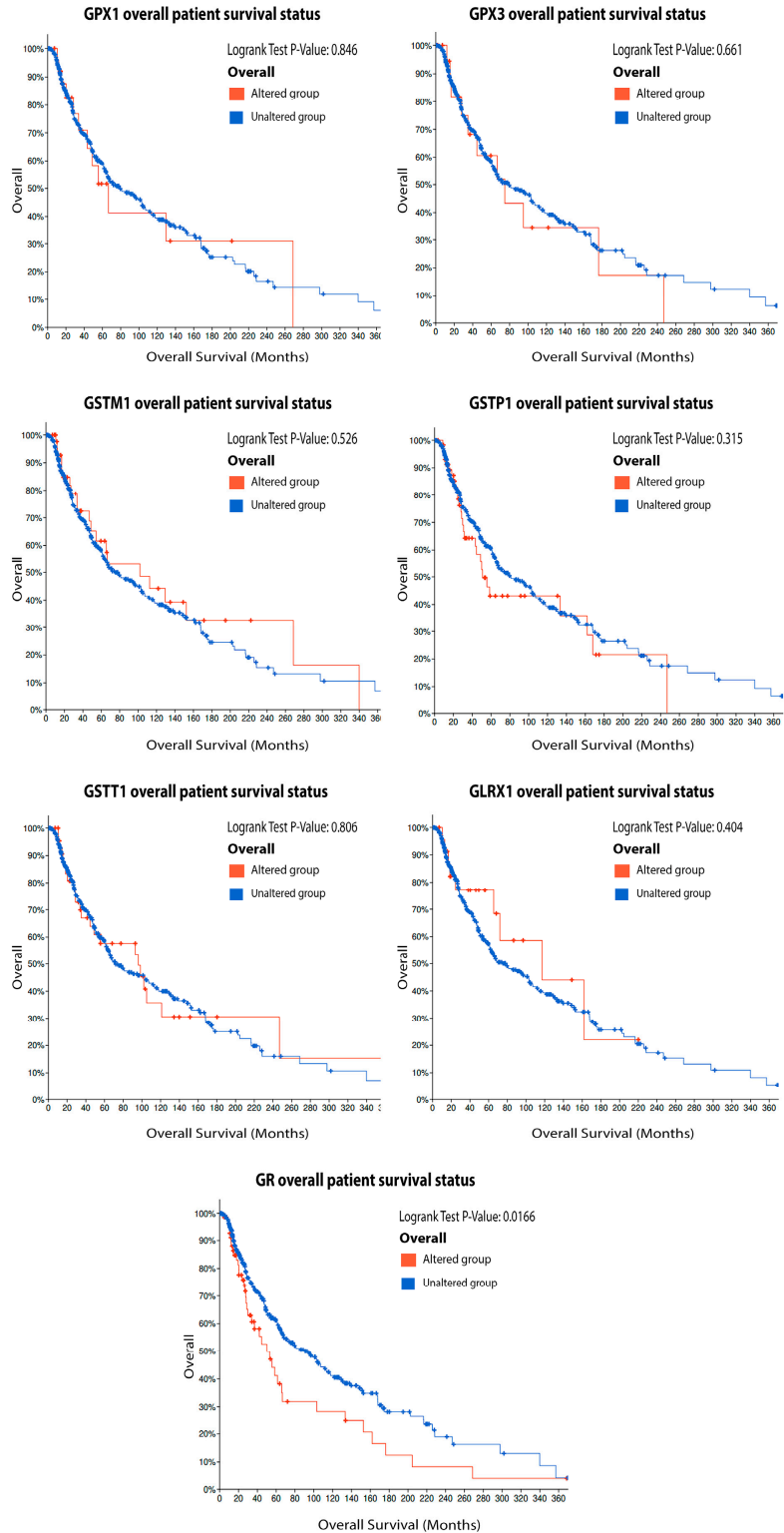

(B)

Figure 5. Cont. 

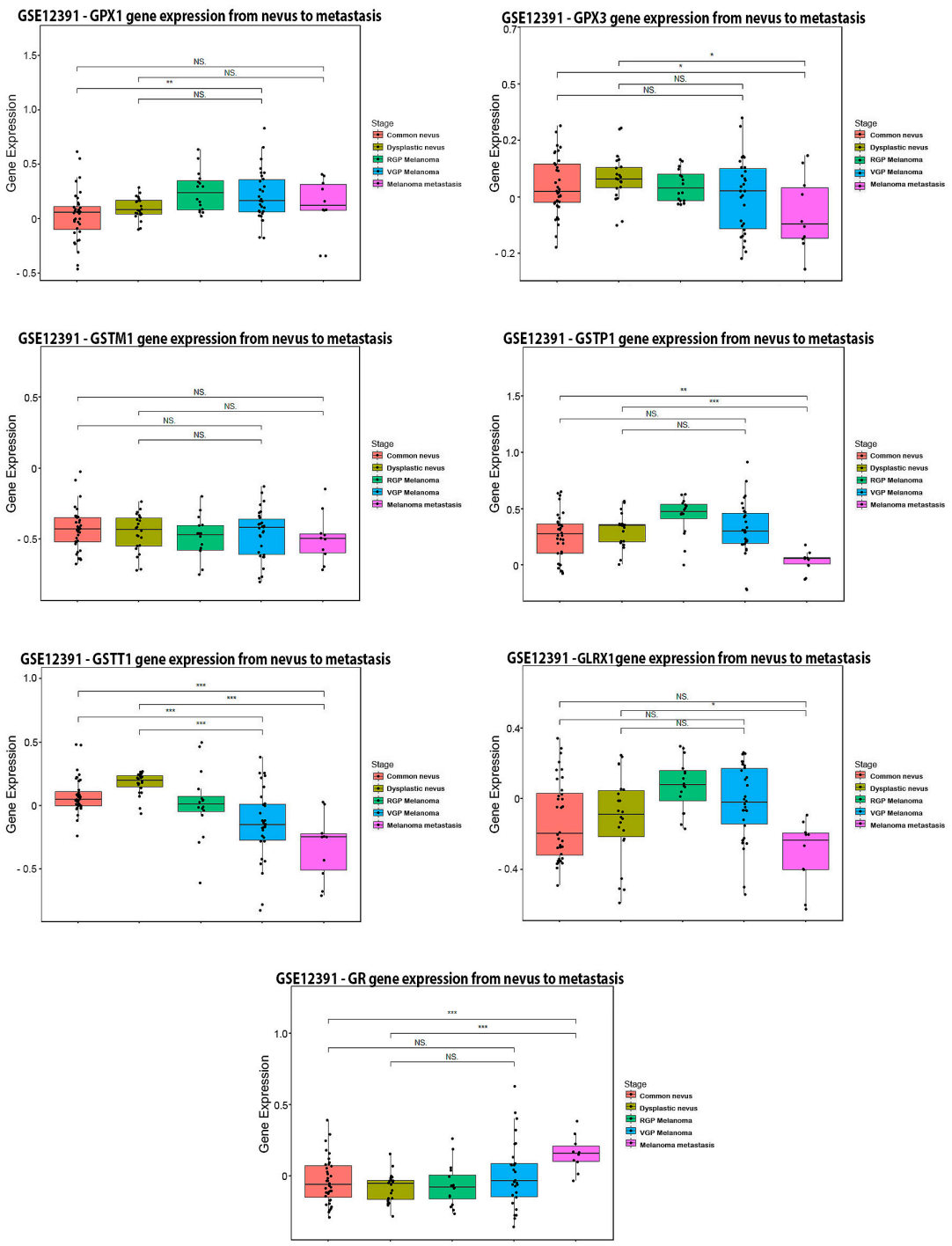

(C)

Figure 5. Glutathione-related enzymes on melanoma. (A) Percentage of patients with altered genes and types of genetic alterations; (B) overall patient survival status, and (C) expression in melanoma progression. Red boxes represent the common nevus, yellow boxes the dysplastic nevus, green boxes the radial growth phase (RGP) melanoma, blue boxes the vertical growth phase (VGP) melanoma, and purple boxes the metastatic melanoma. The statistical analysis was performed by ANOVA followed by Tukey test, ${ }^{* * *} p<0.001,{ }^{* *} p<0.01,{ }^{*} p<0.05$, when compared to common or dysplastic nevus. NS: Not significant.

\subsubsection{Thioredoxin System}

The thioredoxin system is a thiol-reducing system that comprises the thioredoxin (TRX) protein, thioredoxin reductase (TR), TXNIP (thioredoxin interacting protein), and NADPH (coenzyme $\alpha$-nicotinamide adenine dinucleotide phosphate). TRX is a $12 \mathrm{kDa}$ protein with conserved redox catalytic site (-Cys-Gly-Pro-Cys-), responsible for the maintenance of a reducing the intracellular environment state. Mammalian cells have two TRX isoforms: TRX1 present in cytosol and TRX2 in the mitochondria. TRX2 has two cysteines in its active site, while TRX1 has five cysteines and is important for NO signaling [101]. The reduced form of TRX is responsible for the reduction of several oxidized substrates. Besides its antioxidant property, it can translocate to the nucleus upon stimulation and associate with several transcription factors to regulate redox-sensitive genes. TR is a selenoenzyme that 
catalyzes the electron transfer to the oxidized form of TRX and other substrates, using reducing equivalents from NADPH [102]. TR has three isoforms in humans: TR1 present in the cytoplasm, TR2 or TGR in the testis, and TR3 in the mitochondria [101]. TXNIP is an endogenous inhibitor of TRX that binds to its redox-active site, negatively regulating its activity [101].

TRX is overexpressed in both nucleus and cytoplasm compared to tumors of a less aggressive nature [103] and seems to be involved in immune mechanisms in melanoma [104,105]. Overexpression of TXNIP increased transendothelial migration (TEM). Overexpression of TRX blocked hydrogen peroxide-induced TEM, demonstrating a cooperative role of TXNIP in melanoma progression that can be reversed by Trx [106]. Still, higher expression of TXNIP could play an important role in preventing metastasis $[107,108]$. TXNIP is downregulated after BRAFi treatment in melanoma, and overexpression of TXNIP in BRAFi resistant cells decreased migration and invasion [109]. TR1 levels correlate with melanoma progression, and targeting TR1 and glycolysis simultaneously, suppresses the growth of melanoma cells [110]. TR1 knockdown and pharmacological inhibition of TRX lead to decreased melanin levels and reduced activity of tyrosinase, involved in melanin synthesis. TR1 knockdown also caused a delay in upregulation of the melanocyte transcriptional factor MITF [111]. TR is overexpressed in many cancer types and has been recognized as an anti-cancer target. Several studies described the anticancer potential of TR inhibitors [112,113].

Our data analysis in Figure 6 shows that 34\% of the melanoma patients presented alteration on the TRX1 gene, while $7 \%$ showed alterations on TRX2, $8 \%$ on TR1 and TXNIP, $13 \%$ on TR2, and $10 \%$ on TR3. The most common alteration was decreased mRNA expression for TRX1, missense mutation for TRX2, increased mRNA expression for TR1-3, and amplification for TXNIP (Figure 6A). Only the altered group of patients with a mutation on TR2 demonstrated significative impact on patient survival (Figure 6B). TRX1 is significantly decreased in metastasis compared to common and dysplastic nevus (Figure 6C), while TRX2 and TR2 showed no differences in expression (Figure 6C). No data for TR1 and TR3 were found about expression in melanoma progression. TXNIP is significantly decreased in VGP and metastasis (Figure 6C).

161 cases (34\%) with altered genes, out of 470 total cases

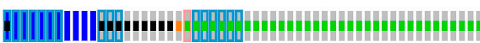

Altered $\longrightarrow 35$ cases $(7 \%)$ with altered genes, out of 470 total cases

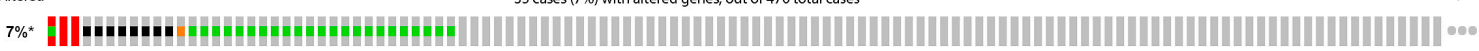
Altered $\longrightarrow 39$ cases $(8 \%)$ with altered genes, out of 470 total cases

Figure 6. Cont. 

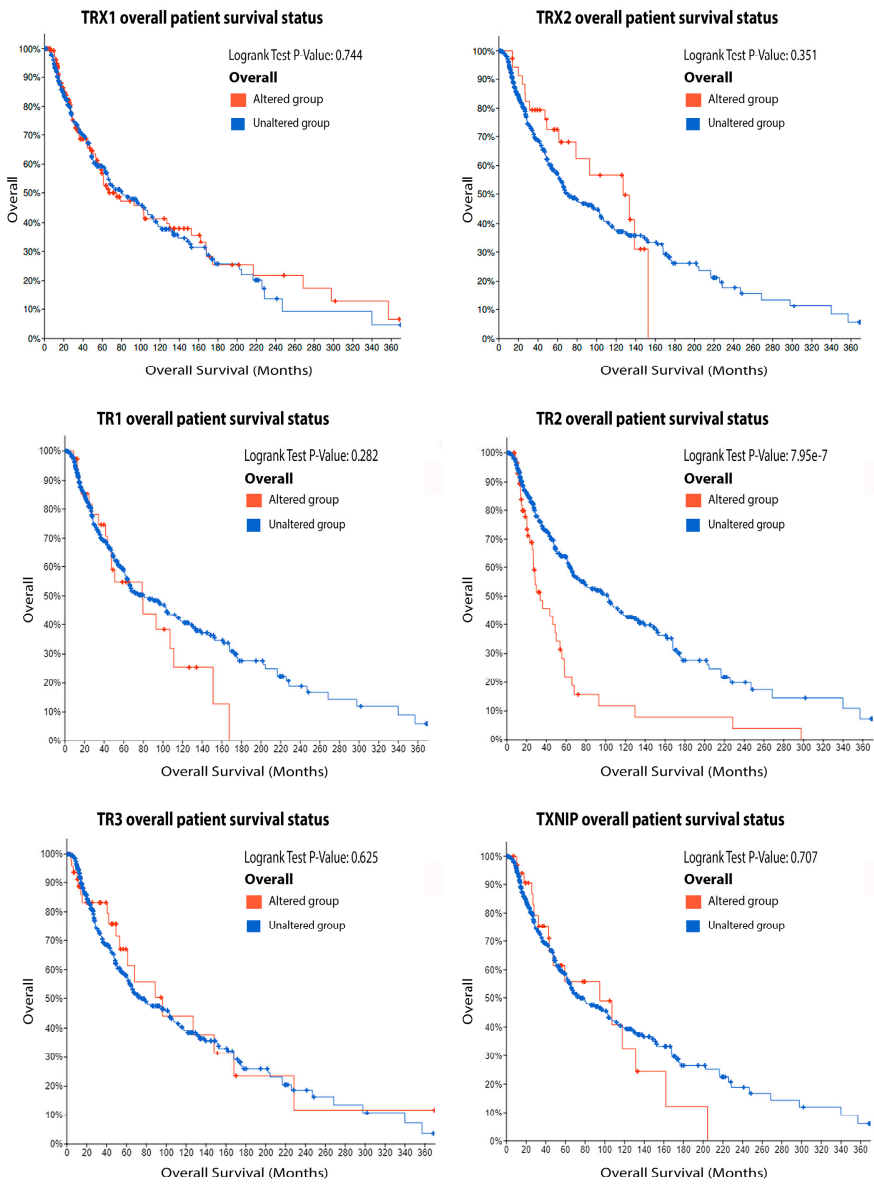

(B)

Figure 6. Cont. 


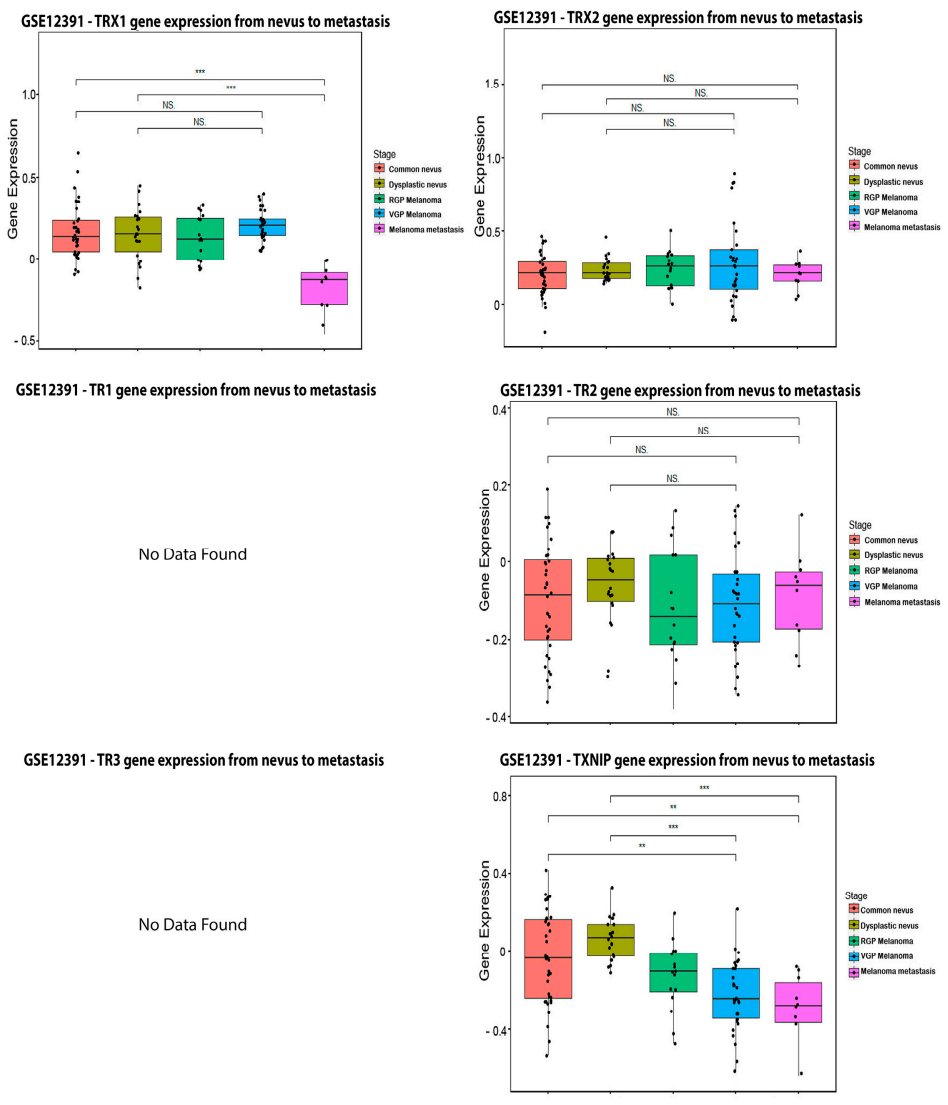

(C)

Figure 6. Thioredoxins, thioredoxins reductase and thioredoxin interacting protein on melanoma. (A) Percentage of patients with altered genes and types of genetic alterations; (B) overall patient survival status, and (C) expression in melanoma progression. Red boxes represent the common nevus, yellow boxes the dysplastic nevus, green boxes the radial growth phase (RGP) melanoma, blue boxes the vertical growth phase (VGP) melanoma, and purple boxes the metastatic melanoma. The statistical analysis was performed by ANOVA followed by Tukey test, ${ }^{* * *} p<0.001,{ }^{* *} p<0.01$, * $p<0.05$ when compared to common or dysplastic nevus. NS: Not significant.

\subsubsection{Peroxiredoxin (PRX)}

Peroxiredoxins are thiol dependent peroxidases that catalyze the reduction of hydrogen peroxide, peroxynitrite and organic hydroperoxides [114-120]. There are six peroxiredoxin isoforms expressed in humans: PRX1, PRX2, and PRX6 in the cytosol and nucleus; PRX3 in the mitochondria; PRX4 in the endoplasmic reticulum; and PRX5 in the cytosol, mitochondria and peroxisomes [119-121]. PRXs possess a 'peroxidatic' cysteine as an oxidation site, and use the reducing equivalents from the thioredoxin system (TR/TRX/NADPH) or the glutaredoxin systems to regenerate the reduced active form [122]. They are emerging as essential enzymes involved in redox signaling [123,124]. 
A study with melanoma patient samples showed that PRX1 and PRX2 are decreased in melanoma compared to nevus, and they could be used as biomarkers of the disease progression [125]. Loss of PRX1 may play a role in melanoma progression, which might not be a mere consequence of carcinogenesis [125]. PRX2 is an onco-suppressor in melanoma. Interestingly, PRX2 seems to be downregulated in melanoma, and is able to prevent metastasis. A natural compound with PRX-like activity (gliotoxin) inhibited proliferation, migration and lung metastasis in PRX2-deficient melanoma cells [126]. Epigenetic loss of PRX2 expression was restored by a demethylating agent [127]. On the opposite, enhanced expression of PRX2 inhibited the apoptosis induced by cisplatin or $\mathrm{H}_{2} \mathrm{O}_{2}$ [128]. Recently, PRX5 was proposed as an oncogene in melanoma, conferring to cells resistance against ROS and RNS [129]. PRX6 is overexpressed in most melanomas, and it can promote proliferation by increasing arachidonic acid-dependent lipid signaling [130]. Melanoma cells abundantly express PRX6, and its iPLA2 activity stimulates proliferation. The knockdown of PRX6 resulted in the suppression of cell proliferation and growth. [130]. Alterations in PRXs expression are also associated with antitumor chemotherapy resistance [130-135].

As observed in Figure 7, 15\% of the melanoma patients have alteration on the PRX1 gene, $7 \%$ on PRX $2,17 \%$ on PRX3, $10 \%$ on PRX $4,8 \%$ on PRX 5 and $14 \%$ on PRX6. The most prevalent type of mutation was increased mRNA expression for PRX1, PRX2, PRX4, PRX5 and PRX6, while the most common mutation for PRX3 was decreased mRNA expression (Figure 7A). Alterations on PRX3 and PRX5 had a significant impact on diminishing patient survival (Figure 7B). PRX1 and PRX5 were increased in melanoma vertical growth phase, and decreased in metastatic melanoma, when compared to normal nevus (Figure 7C). PRX2 and PRX6 were significantly decreased in melanoma compared to nevus (Figure 7C), while PRX3 and PRX4 were increased (Figure 7C).

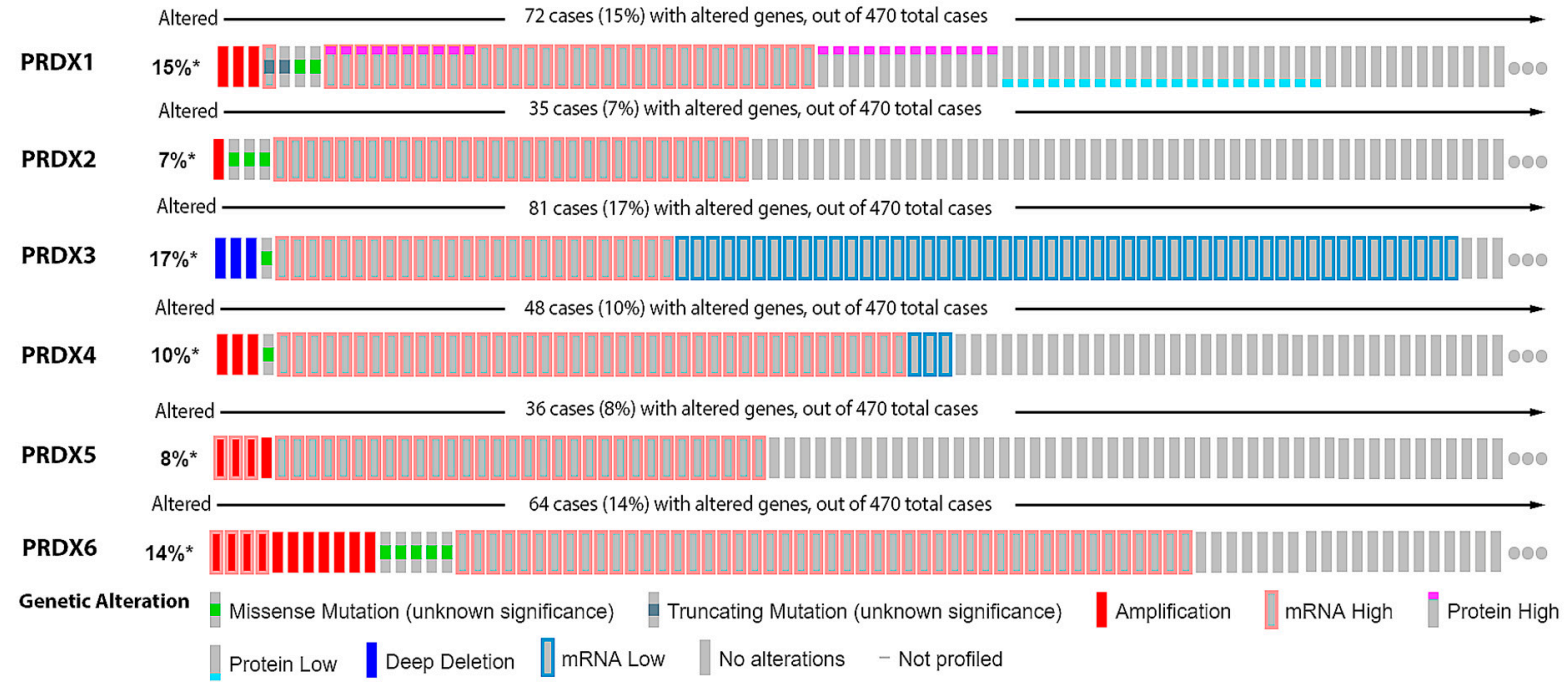

(A)

Figure 7. Cont. 

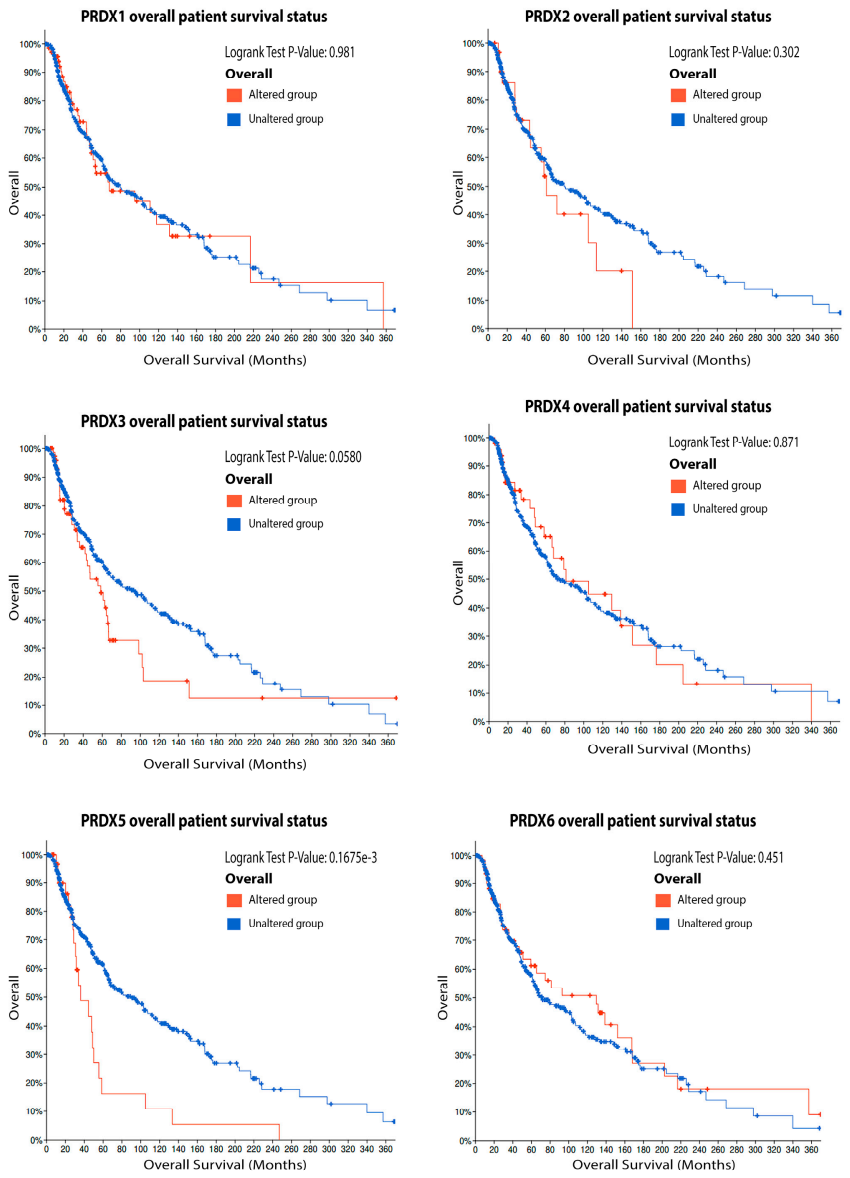

(B)

Figure 7. Cont. 

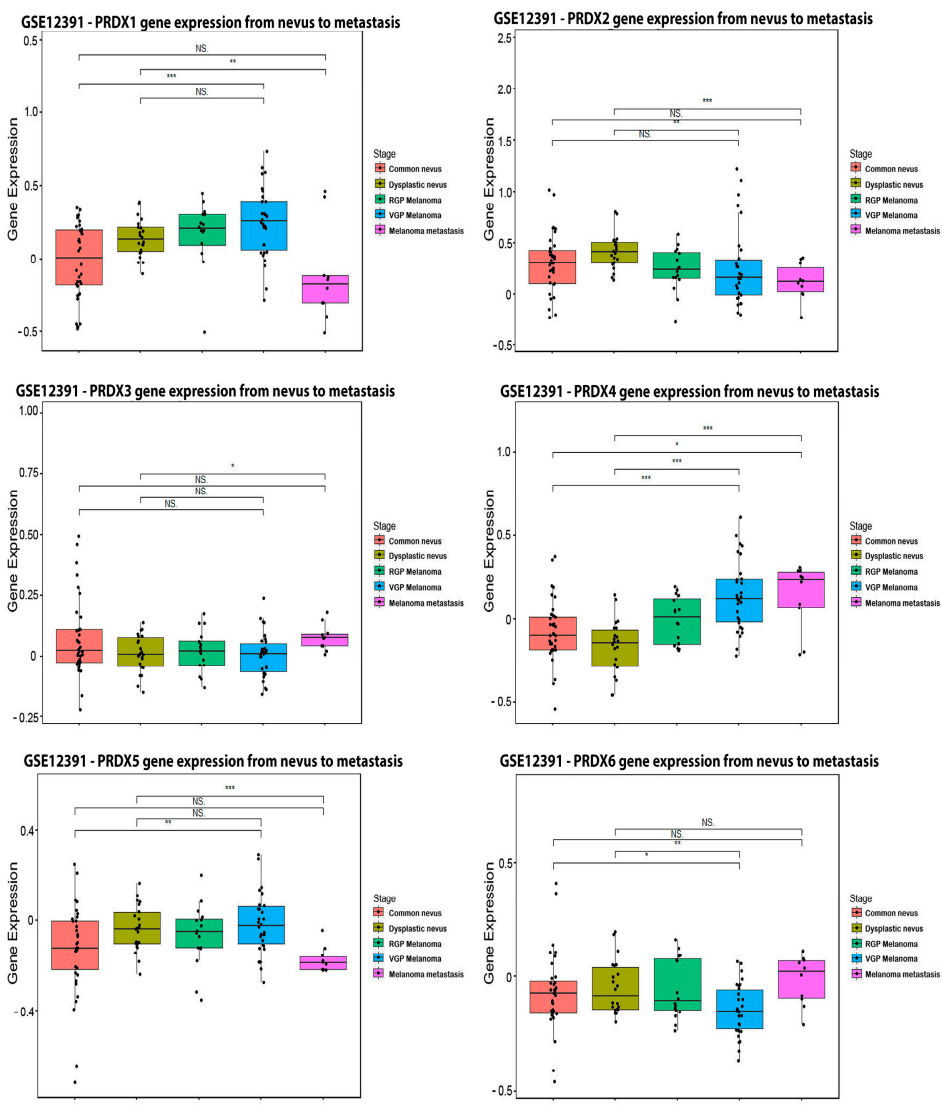

(C)

Figure 7. Peroxiredoxins on melanoma. (A) Percentage of patients with altered genes and types of genetic alterations; (B) overall patient survival status, and (C) expression in melanoma progression. Red boxes represent the common nevus, yellow boxes the dysplastic nevus, green boxes the radial growth phase (RGP) melanoma, blue boxes the vertical growth phase (VGP) melanoma, and purple boxes the metastatic melanoma. The statistical analysis was performed by ANOVA followed by Tukey test, ${ }^{* * *} p<0.001,{ }^{* *} p<0.01,{ }^{*} p<0.05$ when compared to common or dysplastic nevus. NS: Not significant.

\subsubsection{Protein Disulfide Isomerase (PDI)}

Protein disulfide isomerase (PDI) is a $55 \mathrm{kDa}$ chaperone, located in the endoplasmic reticulum (ER), whose functions include a thiol oxidoreductase activity, and also the catalysis of formation, breakage and rearrangement of disulfide bonds [136]. Increased PDI expression correlates with cell migration, metastasis, drug resistance [137-139], and processes related to ER stress [136]. It has been shown that PDI expression was increased in melanoma patients, when compared to normal melanocytes or non-malignant nevus [56,140,141]. Some anti-cancer treatments target the ER, elevating the content of unfolded or misfolded proteins and ER stress. Unfolded protein response (UPR) signaling can increase PDI expression as well [142,143].

The PDI inhibitor bacitracin increased cell death due to the ER stress induced by fenretinide and velcade [144]. Besides, a melanoma cell line expressing a higher basal level of PDI was less sensitive to the ER stress inducer thapsigargin (THG), and the use of bacitracin increased the sensitivity of these cells to THG [145]. In addition, the incubation of melanoma cells with the cell surface PDI inhibitor rutin led to disorganized cytoskeleton projections and decreased cellular migration. The combinatory therapy with rutin and vemurafenib resulted in a decrease in cell survival when compared to the single treatment [56]. Altogether, these results evidenced the importance of PDI in melanoma, and 
point to the potential of PDI inhibitors as promising agents for improving the efficacy of chemotherapy in combinatory therapy for melanoma.

Our analysis showed that $17 \%$ of the melanoma patients have alteration on the PDI gene, with the most prevalent alteration being increased mRNA expression, but this fact has no impact on patient survival (Figure 8A,B). Despite the literature that showed clear evidence for the role of PDI in melanoma, for our bioinformatics analysis (Figure 8C), no significant alteration was observed in PDI (P4HB) expression among the different stages of the disease.

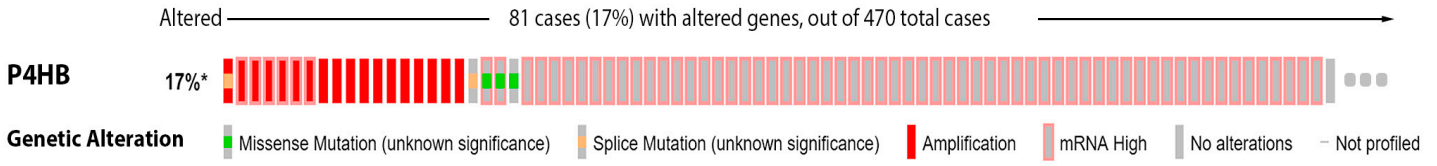

(A)

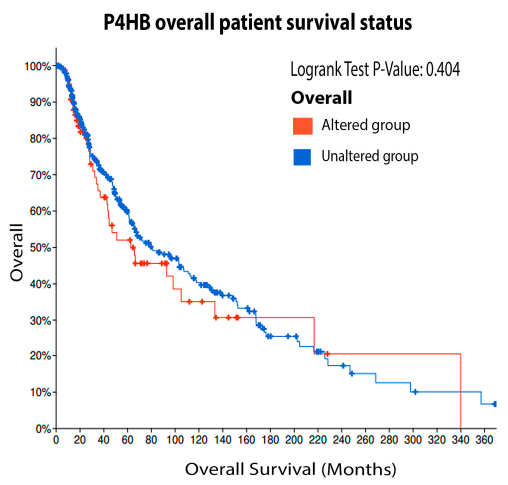

(B)

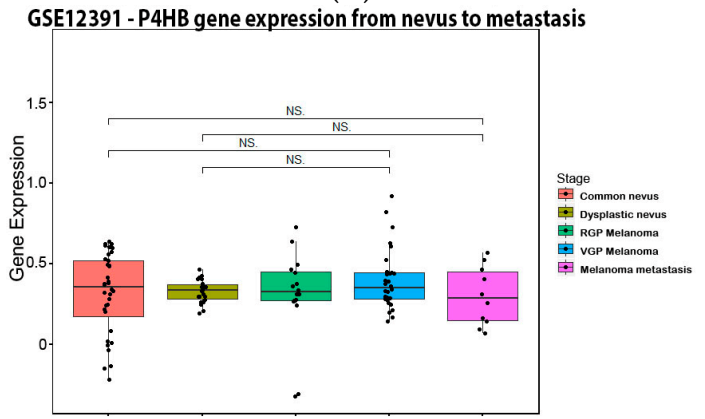

(C)

Figure 8. Protein disulfide isomerase on melanoma. (A) Percentage of patients with altered genes and types of genetic alterations; (B) overall patient survival status, and (C) expression in melanoma progression. Red boxes represent the common nevus, yellow boxes the dysplastic nevus, green boxes the radial growth phase (RGP) melanoma, blue boxes the vertical growth phase (VGP) melanoma, and purple boxes the metastatic melanoma. The statistical analysis was performed by ANOVA followed by Tukey test, ${ }^{*} p<0.05$ when compared to common or dysplastic nevus. NS: Not significant.

\subsubsection{Peroxidasin (PXDN)}

Peroxidasin (PXDN) was initially named melanoma gene 50 (MG50), due to its expression in melanoma samples, which was characterized as a potent melanoma-associated antigen [146]. PXDN is located in the ER and secreted into the extracellular space. It contains a peroxidase domain and other motifs, typical of extracellular proteins [147]. This protein has been identified as a marker in melanoma, glioma and renal carcinoma, playing a possible role in the regulation of tumor angiogenesis [148]. It is increased in invasive mesenchymal-like melanoma cells, showing high expression in metastatic melanoma tumors. PXDN gene silencing led to reduced melanoma invasion in vitro and inhibited 
migration in vivo [149]. Our analysis showed that $13 \%$ of the patients have alteration on the PXDN gene, with the most prevalent mutation being increased mRNA expression, but it has no impact on patient survival (Figure 9A,B). Corroborating literature data, our analysis demonstrated that PXDN is significantly augmented in VGP melanoma (Figure 9C).

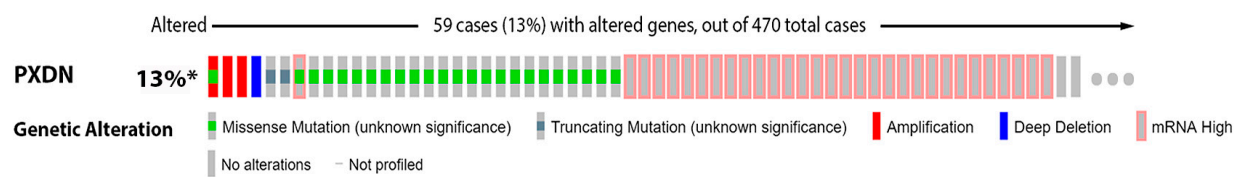

(A)

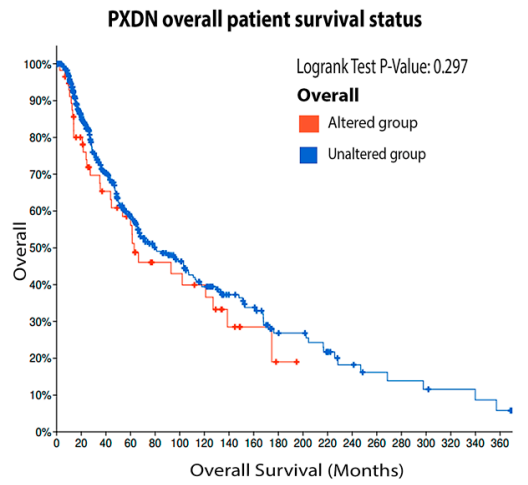

(B)

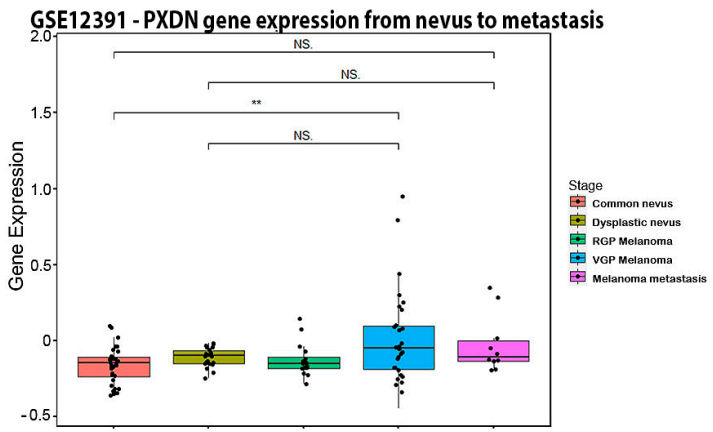

(C)

Figure 9. Peroxidasin on melanoma. (A) Percentage of patients with altered genes and types of genetic alterations; (B) overall patient survival status, and (C) expression in the melanoma progression. Red boxes represent the common nevus, yellow boxes the dysplastic nevus, green boxes the radial growth phase (RGP) melanoma, blue boxes the vertical growth phase (VGP) melanoma, and purple boxes the metastatic melanoma. The statistical analysis was performed by ANOVA followed by Tukey test, ${ }^{* *} p<0.01 * p<0.05$ when compared to common or dysplastic nevus. NS: Not significant.

\section{Discussion}

According to our analysis in melanoma patients, all redox proteins have some type of genetic alteration, which evidences their potential role as biomarkers or targets. The most common alteration was increased mRNA expression ( $78 \%$ of the isoforms), followed by a missense mutation ( $9 \%$ of the isoforms) and decreased mRNA expression ( $9 \%$ of the isoforms). Once data about genetic alteration could not be distinguished by the disease or treatment stage, some contradictory data may be found, which reinforces the need for more careful and specific studies. In this sense, more attention should be given to TRX1, once $34 \%$ of the melanoma patients have some mutation in this gene. The most prevalent alteration was decreased mRNA expression, which corroborates our data about the expression of TRX1 on melanoma progression that is significatively decreased on metastasis. 
Five isoforms showed to be relevant on overall patient survival status: PRX3, PRX5, TR2, GR and NOX4 (15\% of the isoforms). The NOX4 gene is altered in 15\% of the melanoma patients with the most prevalence for increased mRNA expression and amplification, which corroborates with our data about increased NOX4 expression on melanoma metastasis. Interestingly, however, the group with alteration on the NOX4 gene demonstrated longer survival than the unaltered group. This calls attention to the real role of NOX4 in melanoma. PRX3, PRX5 and GR are antioxidant proteins that contribute to ROS detoxification and not ROS formation like NOX4. The lack of alterations on PRX3, PRX5, TR2 and GR showed to be important for higher patient survival. In fact, PRX5 seems to be decreased in metastasis, while PRX3 and GR seem to be increased at this stage. TR2, however, did not show a significant expression from nevus to metastasis. Again, the lack of more consistent information about the disease stage or if the patient was under treatment or relapse leave some doubts about the real role of these proteins on melanoma. However, it highlights the importance of these redox proteins on survival.

We summarized patient data about disease progression obtained from a public microarray database [24], as shown in Figure 10. These results show that the proteins NOS2, SOD1, GPX1, NOX2, NOX4, PRX1, PRX4, PRX5 and PXDN are increased in the vertical growth phase, while SOD3, CAT, GSTT1, NOX1, PRX2 and PRX6 are decreased. Besides, NOS2, GSR, NOX2, NOX4, PRX3, PRX4 and PRX6 are increased in metastasis, while SOD3, CAT, GLRX, GSTP1, GSTT1, TXN, PRX1, PRX2 and PRX5 are decreased. These results evidence that different isoforms of the same protein could play opposite roles in melanoma, such as SOD1 and SOD3; NOX1, NOX2 and NOX4, and all PRXs. Furthermore, the same isoform could be increased or decreased depending on the stage of the disease, such as PRX1, PRX5 and PRX6. These data highlight the importance of discriminating protein isoforms and disease stages in the studies in order to achieve a more precise and complete understanding of the role of each protein, avoiding a non-specific and possible harmful therapy aiming at the inhibition of proteins that are already reduced.

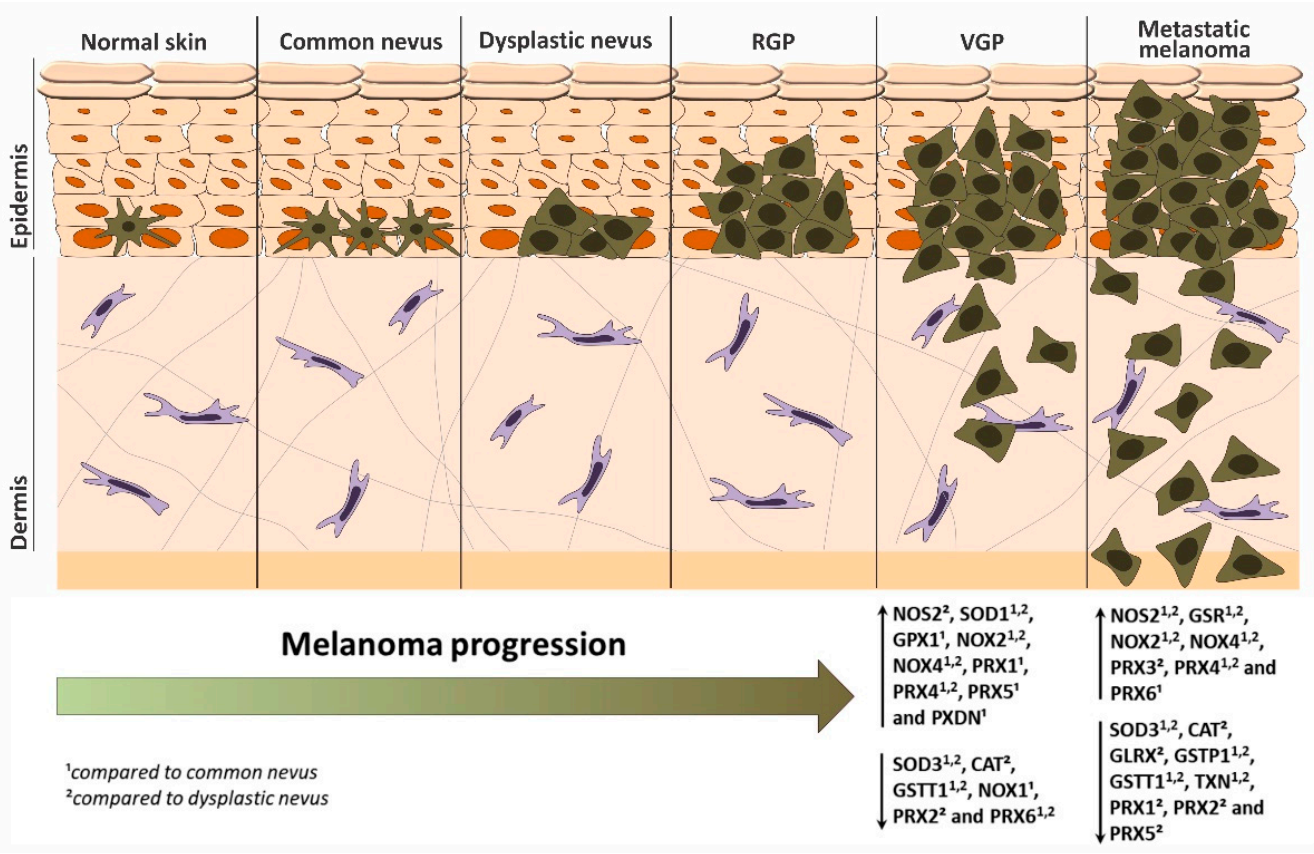

Figure 10. Expression of RNS/ROS-generating and detoxifying proteins in melanoma progression. Thin arrows indicate an increase $(\uparrow)$ or decrease $(\downarrow)$ of proteins in VGP and metastatic melanoma compared to ${ }^{1}$ common nevus or ${ }^{2}$ dysplastic nevus. RGP: radial-growth phase. VGP: vertical-growth phase.

We also summarized literature information found and some analyzed data in Tables 1 and 2. These data evidence some lack of information about the expression of specific proteins, such as SOD3, PRX4, PRX5, NOX2, NOX3, NOS3, TRX2, TR2, TR3, 
GLRX1, and GR in melanoma. Additionally, studies investigating the expression of these proteins in sensitive or chemoresistant melanoma are necessary, in which we also observed differences in the expression of some proteins, such as PRX1 and PRX3.

Table 1. Expression of redox sensitive proteins in melanoma. NDF: no data found.

\begin{tabular}{|c|c|c|c|c|c|}
\hline Protein & Function & Expression & $\begin{array}{l}\text { Inhibitors and Study } \\
\text { Model }\end{array}$ & Effect & References \\
\hline \multirow{2}{*}{ CAT } & \multirow{2}{*}{$\begin{array}{l}\text { Converts } \mathrm{H}_{2} \mathrm{O}_{2} \text { to } \\
\mathrm{O}_{2} \text { and } \mathrm{H}_{2} \mathrm{O} \text {. }\end{array}$} & $\begin{array}{c}\downarrow \text { healthy } \\
\text { melanocytes }\end{array}$ & \multirow{2}{*}{$\begin{array}{l}\text { PEG-Catalase } \rightarrow \text { in vitro, } \\
\text { in vivo within mouse } \\
\text { xenograft model } \\
3-\mathrm{AT} \rightarrow \text { in vitro }\end{array}$} & \multirow{2}{*}{$\begin{array}{l}\text { Less proliferation, } \\
\text { migration and metastasis, } \\
\text { restore intercellular ROS } \\
\text { signaling, induce apoptosis. }\end{array}$} & \multirow{2}{*}[67-69,71,72,150]{} \\
\hline & & $\begin{array}{l}\uparrow \text { melanoma } \\
\text { patients }\end{array}$ & & & \\
\hline $\begin{array}{l}\text { CuZnSOD } \\
\text { (SOD1) }\end{array}$ & \multirow{4}{*}{$\begin{array}{c}\text { dismutase-type } \\
\text { enzyme; catalyzes the } \\
\text { dismutation reaction to } \\
\text { convert } \mathrm{O}_{2}^{-\bullet} \text { into } \\
\mathrm{H}_{2} \mathrm{O}_{2} .\end{array}$} & $\begin{array}{l}\uparrow \text { melanoma } \\
\text { cell aging }\end{array}$ & $\begin{array}{c}\text { ATN-224 } \rightarrow \text { in vitro; } \\
\text { in vivo; and randomized } \\
\text { trials in humans } \\
\text { DSF/DCC } \rightarrow \text { in vitro }\end{array}$ & $\begin{array}{l}\text { Less proliferation, } \\
\text { antiangiogenic activity, and } \\
\text { proapoptotic effects. }\end{array}$ & {$[63,151-155]$} \\
\hline \multirow{2}{*}{$\begin{array}{l}\text { MnSOD } \\
\text { (SOD2) }\end{array}$} & & $\begin{array}{c}\downarrow \text { B16F10 cell } \\
\text { line; melanoma } \\
\text { patients }\end{array}$ & \multirow[t]{2}{*}{ NDF } & \multirow[t]{2}{*}{ NDF } & {$[59]$} \\
\hline & & $\begin{array}{l}\uparrow \text { melanoma } \\
\text { patients }\end{array}$ & & & {$[61,69,151]$} \\
\hline ecSOD (SOD3) & & NDF & NDF & NDF & $\mathrm{NDF}$ \\
\hline \multirow[b]{2}{*}{ PRX1 } & \multirow{7}{*}{$\begin{array}{c}\text { Catalyzes the reduction } \\
\text { of hydrogen peroxide, } \\
\text { peroxynitrite and } \\
\text { organic hydroperoxide. }\end{array}$} & $\begin{array}{c}\uparrow \text { in } \\
\text { chemotherapy }\end{array}$ & \multirow{7}{*}{$\begin{array}{c}\text { Gliotoxin } \rightarrow \text { in vitro, } \\
\text { in vivo } \\
\text { Frenolicin } \mathrm{B} \rightarrow \text { in vitro } \\
\text { (colon, breast and lung } \\
\text { cancer cell lines), in vivo } \\
\text { Conoidin } \mathrm{A} \rightarrow \text { in vitro } \\
\text { (colorectal cancer cells) }\end{array}$} & \multirow{7}{*}{$\begin{array}{l}\text { Less proliferation, growth, } \\
\text { migration and promotes } \\
\text { cell death. }\end{array}$} & \multirow[b]{2}{*}[125,131,132,134,156]{} \\
\hline & & $\begin{array}{l}\downarrow \text { melanoma } \\
\text { compared to } \\
\text { nevus }\end{array}$ & & & \\
\hline PRX2 & & $\begin{array}{l}\downarrow \text { melanoma } \\
\text { compared to } \\
\text { nevus }\end{array}$ & & & [125-127] \\
\hline PRX3 & & $\begin{array}{l}\downarrow \text { melanoma } \\
\text { with } \\
\text { methylation }\end{array}$ & & & {$[125-127,157]$} \\
\hline PRX4 & & $\begin{array}{c}\uparrow \text { and } \uparrow \text { in } \\
\text { chemotherapy }\end{array}$ & & & {$[133,135]$} \\
\hline PRX5 & & NDF & & & $\mathrm{NDF}$ \\
\hline PRX6 & & $\mathrm{NDF}$ & & & NDF \\
\hline PXDN & $\begin{array}{l}\text { Forms a sulfilimine } \\
\text { bond through the } \\
\text { synthesis of } \\
\text { hypohalous acids. }\end{array}$ & $\begin{array}{l}\uparrow \text { melanoma } \\
\text { patients }\end{array}$ & NDF & $\mathrm{NDF}$ & {$[131]$} \\
\hline PDI & $\begin{array}{l}\text { Catalyzes the } \\
\text { formation, } \\
\text { isomerization and } \\
\text { removal of disulfide } \\
\text { bonds. }\end{array}$ & $\begin{array}{l}\uparrow \text { melanoma } \\
\text { patients }\end{array}$ & $\begin{array}{c}\text { Bacitracin } \rightarrow \text { in vitro } \\
\text { Rutin } \rightarrow \text { in vivo, in vitro, } \\
\text { in silico }\end{array}$ & $\begin{array}{l}\text { Less migration, cell death } \\
\text { and disorganization of the } \\
\text { cytoskeleton-including in } \\
\text { resistance }\end{array}$ & $\begin{array}{l}{[55,140,141,144,} \\
158-160]\end{array}$ \\
\hline NOX1 & \multirow{5}{*}{$\begin{array}{l}\text { Reduces oxygen to } \\
\text { superoxide radical } \\
\left(\mathrm{O}_{2}^{-\bullet}\right) \text { and } \mathrm{H}_{2} \mathrm{O}_{2} \text {. }\end{array}$} & $\begin{array}{l}\uparrow \text { melanoma } \\
\text { cells }\end{array}$ & \multirow{5}{*}{$\begin{array}{c}\text { DPI } \rightarrow \text { in vitro } \\
\text { Apocynin } \rightarrow \text { in vitro, } \\
\text { in vivo } \\
\text { VAS2870 } \rightarrow \text { in vitro } \\
\text { Honokiol } \rightarrow \text { in vitro, } \\
\text { in vivo } \\
\text { ML171, GKT136901, } \\
\text { GSK2795039, GLX7013114, } \\
\text { APX-115 (non-specific for } \\
\text { melanoma) }\end{array}$} & \multirow{5}{*}{$\begin{array}{l}\text { Less proliferation, less cell } \\
\text { migration, decreased ROS } \\
\text { production. }\end{array}$} & \multirow{5}{*}[19,51,52,54,56,161]{} \\
\hline NOX2 & & NDF & & & \\
\hline NOX3 & & NDF & & & \\
\hline NOX4 & & $\begin{array}{l}\uparrow \text { melanoma } \\
\text { cells }\end{array}$ & & & \\
\hline NOX5 & & $\begin{array}{l}\uparrow \text { melanoma } \\
\text { cells }\end{array}$ & & & \\
\hline nNOS (NOS1) & \multirow{3}{*}{$\begin{array}{l}\text { Catalyzes the reaction } \\
\text { of L-arginine and } \\
\text { oxygen to produce } \\
\text { L-citrulline and NO. }\end{array}$} & $\begin{array}{l}\uparrow \text { melanoma } \\
\text { associated with } \\
\text { more } \\
\text { proliferative } \\
\text { profile }\end{array}$ & \multirow{3}{*}{$\begin{array}{c}\text { L-NAME } \rightarrow \text { in vitro, } \\
\text { in vivo } \\
\text { L-NIL } \rightarrow \text { in vitro, in vivo } \\
\text { L-NoArg } \rightarrow \text { in vitro, } \\
\text { in vivo } \\
\text { Amg } \rightarrow \text { in vitro, in vivo } \\
\text { Smt } \rightarrow \text { in vitro, in vivo } \\
\text { Evodiamine } \rightarrow \text { in vitro, } \\
\text { in vivo }\end{array}$} & \multirow{3}{*}{$\begin{array}{l}\text { Less proliferation, growth, } \\
\text { antiangiogenic activity, } \\
\text { apoptosis. }\end{array}$} & \multirow{3}{*}{$\begin{array}{c}{[33,38,42,44,46} \\
162-164]\end{array}$} \\
\hline iNOS (NOS2) & & $\begin{array}{c}\uparrow \\
\text { mesenchymal } \\
\text { stem cells } \\
\text { lacking p53 } \\
\text { when exposed } \\
\text { to melanoma } \\
\text { cells }\end{array}$ & & & \\
\hline eNOS (NOS3) & & NDF & & & \\
\hline
\end{tabular}


Table 1. Cont.

\begin{tabular}{|c|c|c|c|c|c|}
\hline Protein & Function & Expression & $\begin{array}{c}\text { Inhibitors and Study } \\
\text { Model }\end{array}$ & Effect & References \\
\hline TRX1 & \multirow{2}{*}{$\begin{array}{l}\text { Maintenance of a } \\
\text { reducing intracellular } \\
\text { environment state. }\end{array}$} & $\begin{array}{l}\uparrow \text { nucleus and } \\
\text { cytoplasm }\end{array}$ & \multirow{2}{*}{ NDF } & \multirow{2}{*}{ NDF } & [103] \\
\hline TRX2 & & NDF & & & $\mathrm{NDF}$ \\
\hline TR1 & \multirow{3}{*}{$\begin{array}{l}\text { Catalyzes the electron } \\
\text { transfer to the oxidized } \\
\text { form of TRX and other } \\
\text { substrates. }\end{array}$} & $\begin{array}{l}\uparrow \text { melanoma } \\
\text { patients }\end{array}$ & \multirow{3}{*}{$\begin{array}{l}\text { MJ25 } \rightarrow \text { in vitro } \\
\text { Auranofin } \rightarrow \text { in vivo } \\
\text { NACC } \rightarrow \text { in vitro }\end{array}$} & \multirow{3}{*}{$\begin{array}{l}\text { Increase ROS levels, induce } \\
\text { p53 expression and cell } \\
\text { death. }\end{array}$} & {$[110,113,165]$} \\
\hline TR2 & & NDF & & & NDF \\
\hline TR3 & & NDF & & & NDF \\
\hline TXNIP & $\begin{array}{l}\text { Endogenous inhibitor } \\
\text { of TRX. }\end{array}$ & $\begin{array}{l}\downarrow \text { in VGP and } \\
\text { metastasis }\end{array}$ & NDF & $\mathrm{NDF}$ & {$[108,109]$} \\
\hline GPX1 & \multirow{2}{*}{$\begin{array}{c}\text { Detoxification of } \\
\text { organic and inorganic } \\
\text { peroxides. }\end{array}$} & $\begin{array}{l}\uparrow \text { melanoma } \\
\text { cells }\end{array}$ & \multirow{4}{*}{$\begin{array}{c}\text { BSO } \rightarrow \text { in vitro, in vivo, } \\
\text { and clinical trials with } \\
\text { humans } \\
\text { Lomefloxacin } \rightarrow \text { in vitro } \\
\text { NBDHEX and MC } 3181 \\
\text { (derivative) } \rightarrow \text { in vitro, } \\
\text { in vivo within xenograft } \\
\text { mouse model } \\
\text { Ethacrynic acid } \rightarrow \text { in vitro } \\
\text { Curcumin } \rightarrow \text { in vitro, } \\
\text { in silico }\end{array}$} & \multirow{4}{*}{$\begin{array}{l}\text { Less proliferation, } \\
\text { migration, and induction of } \\
\text { apoptosis and overcome } \\
\text { melanoma resistance. }\end{array}$} & \multirow{2}{*}[82,83,87,88]{} \\
\hline GPX3 & & $\downarrow \underset{\text { cells }}{\downarrow}$ & & & \\
\hline \multirow[b]{2}{*}{ GST } & \multirow[b]{2}{*}{$\begin{array}{l}\text { Catalyzes the } \\
\text { conjugation of GSH. }\end{array}$} & $\begin{array}{c}\uparrow \text { in tumor } \\
\text { progression. }\end{array}$ & & & \multirow[b]{2}{*}{ [86,90,91,94,166-169] } \\
\hline & & $\begin{array}{c}\downarrow \text { metastasis } \\
\text { derived from } \\
\text { skin or lymph } \\
\text { nodes }\end{array}$ & & & \\
\hline GLRX1 & $\begin{array}{l}\text { Glutathione-disulfide } \\
\text { oxidoreductase activity. }\end{array}$ & NDF & NDF & NDF & NDF \\
\hline GR & $\begin{array}{c}\text { Catalyzes the reduction } \\
\text { of GSSG to GSH. }\end{array}$ & NDF & 2 -AAPA $\rightarrow$ in vitro & $\begin{array}{c}\text { Less proliferation, } \\
\text { migration, invasion, } \\
\text { induction of apoptosis. }\end{array}$ & {$[100,169,170]$} \\
\hline
\end{tabular}

Table 2. Patient data about genetic alteration, survival status and gene expression of redox sensitive proteins in melanoma progression. * compared to common nevus / ${ }^{* *}$ compared to dysplastic nevus. NSD: no significant difference. NDF: no data found.

\begin{tabular}{|c|c|c|c|c|c|}
\hline \multirow[b]{2}{*}{ Protein } & \multirow{2}{*}{$\begin{array}{c}\text { Genetic } \\
\text { Alteration (Out } \\
\text { of } 470 \text { Cases) }\end{array}$} & \multirow{2}{*}{$\begin{array}{c}\% \text { of Patients with } \\
\text { Alteration on the } \\
\text { Gene/Main Alteration }\end{array}$} & \multirow{2}{*}{$\begin{array}{c}\text { Overall Patient } \\
\text { Survival ( } p \text {-Value) }\end{array}$} & \multicolumn{2}{|c|}{ Gene Expression } \\
\hline & & & & $\begin{array}{c}\text { VGP } \\
\text { Melanoma }\end{array}$ & $\begin{array}{l}\text { Melanoma } \\
\text { Metastasis }\end{array}$ \\
\hline CAT & 45 cases $(10 \%)$ & $10 \%$ mRNA high & 0.626 & $\downarrow^{* *}$ & $\downarrow^{* *}$ \\
\hline SOD1 & 68 cases $(14 \%)$ & $14 \%$ mRNA high & 0.537 & $\uparrow * / * *$ & NSD \\
\hline SOD2 & 34 cases $(7 \%)$ & $7 \%$ mRNA high & 0.124 & NSD & NSD \\
\hline SOD3 & 21 cases $(4 \%)$ & 4\% mRNA high & 0.969 & $\downarrow * / * *$ & $\downarrow^{*} / * *$ \\
\hline PRX1 & 72 cases $(15 \%)$ & 15\% mRNA high & 0.981 & $\uparrow *$ & $\downarrow *$ \\
\hline PRX2 & 35 cases $(7 \%)$ & $7 \%$ mRNA high & 0.302 & $\downarrow^{*}$ & $\downarrow^{*}$ \\
\hline PRX3 & 81 cases $(17 \%)$ & 17\% mRNA low & 0.0580 & NSD & $\uparrow * *$ \\
\hline PRX4 & 48 cases $(10 \%)$ & $10 \%$ mRNA high & 0.871 & $\uparrow * / * *$ & $\uparrow * / * *$ \\
\hline PRX5 & 36 cases $(8 \%)$ & $8 \%$ mRNA high & $1.675 \times 10^{-3}$ & $\uparrow *$ & $\downarrow^{*}$ \\
\hline PRX6 & 64 cases $(14 \%)$ & $14 \%$ mRNA high & 0.451 & $\downarrow * / * *$ & $\uparrow *$ \\
\hline PXDN & 59 cases $(13 \%)$ & $13 \%$ mRNA high & 0.297 & $\uparrow *$ & NSD \\
\hline PDI & 81 cases $(17 \%)$ & 17\% mRNA high & 0.404 & NSD & NSD \\
\hline NOX1 & 59 cases $(13 \%)$ & $13 \%$ mRNA high & 0.140 & $\downarrow^{*}$ & NSD \\
\hline NOX2 & 34 cases $(17 \%)$ & $7 \%$ mRNA high & 0.258 & $\uparrow * / * *$ & $\uparrow * / * *$ \\
\hline NOX3 & 31 cases $(7 \%)$ & 7\% mRNA high & 0.576 & NSD & NSD \\
\hline NOX4 & 69 cases $(15 \%)$ & 15\% mRNA high & 0.0286 & $\uparrow * / * *$ & $\uparrow * / * *$ \\
\hline NOX5 & 33 cases $(7 \%)$ & $7 \%$ missense mutation & 0.775 & NSD & NSD \\
\hline
\end{tabular}


Table 2. Cont.

\begin{tabular}{|c|c|c|c|c|c|}
\hline \multirow[b]{2}{*}{ Protein } & \multirow{2}{*}{$\begin{array}{c}\text { Genetic } \\
\text { Alteration (Out } \\
\text { of } 470 \text { Cases) }\end{array}$} & \multirow{2}{*}{$\begin{array}{c}\text { \% of Patients with } \\
\text { Alteration on the } \\
\text { Gene/Main Alteration }\end{array}$} & \multirow{2}{*}{$\begin{array}{c}\text { Overall Patient } \\
\text { Survival ( } p \text {-Value) }\end{array}$} & \multicolumn{2}{|c|}{ Gene Expression } \\
\hline & & & & $\begin{array}{c}\text { VGP } \\
\text { Melanoma }\end{array}$ & $\begin{array}{l}\text { Melanoma } \\
\text { Metastasis }\end{array}$ \\
\hline nNOS (NOS1) & 67 cases $(14 \%)$ & $14 \%$ missense mutation & 0.978 & NSD & NSD \\
\hline iNOS (NOS2) & 38 cases $(8 \%)$ & $8 \%$ mRNA high & 0.618 & $\uparrow * *$ & $\uparrow * / * *$ \\
\hline eNOS (NOS3) & 83 cases $(18 \%)$ & 18\% mRNA high & 0.156 & NSD & NSD \\
\hline TRX1 & 161 cases $(34 \%)$ & $34 \%$ mRNA low & 0.744 & NSD & $\downarrow * / * *$ \\
\hline TRX2 & 35 cases $(7 \%)$ & $7 \%$ missense mutation & 0.351 & NSD & NSD \\
\hline TR1 & 39 cases $(8 \%)$ & 8\% mRNA high & 0.282 & NDF & $\mathrm{NDF}$ \\
\hline TR2 & 63 cases $(13 \%)$ & 14\% mRNA high & $7.95 \times 10^{-7}$ & NSD & NSD \\
\hline TR3 & 48 cases $(10 \%)$ & 10\% mRNA high & 0.625 & $\mathrm{NDF}$ & $\mathrm{NDF}$ \\
\hline TXNIP & 37 cases $(8 \%)$ & $8 \%$ amplification & 0.707 & $\downarrow^{*} / * *$ & $\downarrow^{*} / * *$ \\
\hline GPX1 & 28 cases $(6 \%)$ & $6 \%$ mRNA high & 0.846 & $\uparrow *$ & NSD \\
\hline GPX3 & 22 cases $(5 \%)$ & $5 \%$ mRNA high & 0.661 & NSD & $\downarrow * / * *$ \\
\hline GSTM1 & 46 cases $(10 \%)$ & 10\% mRNA high & 0.526 & NSD & NSD \\
\hline GSTP1 & 61 cases $(13 \%)$ & 13\% mRNA high & 0.315 & NSD & $\downarrow^{*} / * *$ \\
\hline GSTT1 & 49 cases $(10 \%)$ & 10\% mRNA high & 0.806 & $\downarrow^{*} / * *$ & $\downarrow * / * *$ \\
\hline GLRX1 & 64 cases $(14 \%)$ & $5 \%$ mRNA high & 0.404 & NSD & $\downarrow^{* *}$ \\
\hline GR & 72 cases $(15 \%)$ & $15 \%$ mRNA low & 0.0166 & NSD & $\uparrow * / * *$ \\
\hline
\end{tabular}

If we consider total proteins and no longer the isoforms, the numbers of alterations become even more evident. We have $100 \%$ of the genetically altered proteins, $44 \%$ of the proteins impacting on patient survival, and $89 \%$ of proteins differentially expressed in disease progression. So, despite the great advance in melanoma field about the redox metabolism in the last years, we still have some gaps in the area that should be investigated further.

\section{Conclusions}

Increasing shreds of evidence point to oxidative stress as one factor responsible for cancer development, progression and metastasis. Treatments with BRAF and MEK inhibitors have been shown to increase ROS in melanoma. Thus, targeting the antioxidant system may contribute to overcoming resistance. Meanwhile, cancer cells are highly adaptive. They cooperate with antioxidant systems to survive in such stressful conditions. By understanding the complex mechanisms involved in adaptation and searching for new targets to make cells more susceptible to treatment, the disease might be overcome. Indeed, exploring the role of redox sensitive proteins and the modulation of redox homeostasis may provide clues to new therapeutic benefits. They may be involved in both disease progression and resistance to chemotherapy. In this sense, they could act as biomarkers, and therefore, possibly as targets to overcome resistance. According to our bioinformatics analysis, all isoforms showed to be genetically altered in some patients, with emphasis on TRX1 which is altered in $34 \%$ of patients. The isoforms PRX3, PRX5, TR2, GR and NOX4 demonstrated to impact on patient survival. Besides, iNOS, SOD1, NOX4, PRX3, PXDN and GPX1 are generally increased during melanoma progression, while CAT, GPX3, TXNIP and PRX2 are decreased. These observations are corroborated by the aforementioned literature. For TRX1 and NOX1, our data analysis is paradoxical with some former studies, and this apparent inconsistency might be due to different models used in each case. Our gene expression analysis is derived from biopsies obtained from different patients, while other articles use cell lines or animals. Besides, the stage of the disease could influence the result as well. For example, the levels of PRX1, PRX5 and PRX6 can be increased or decreased depending on 
the stage. Ultimately, inhibitors or mimetics of these redox sensitive proteins have achieved very promising results. Although no such specific antioxidant therapy is approved for melanoma yet, we foresee that forthcoming investigations on the modulation of these proteins will bring great advances for cancer therapy.

Author Contributions: Conceptualization, L.A.C.C. and S.S.M.-E.; methodology, L.A.C.C., R.G.Q. and Á.D.D.S.; formal analysis and investigation, L.A.C.C., R.G.Q. and A.L.B.B.; writing-original draft preparation, L.A.C.C. and S.S.M.-E.; writing-review and editing, L.A.C.C., R.G.Q., A.L.B.B., Á.D.D.S., W.A.S.J., T.R. and S.S.M.-E.; supervision and funding acquisition, S.S.M.-E. All authors have read and agreed to the published version of the manuscript.

Funding: This research was funded by FAPESP, grant numbers 17/04926-6, 18/14936-1 and 21/05150-7; CNPq, grant numbers \#408769/2018, \#304339/2017-2 and \#312020/2019-8 and CAPES.

Institutional Review Board Statement: Not applicable.

Informed Consent Statement: Not applicable.

Data Availability Statement: Data is contained within the article.

Conflicts of Interest: The authors declare no conflict of interest.

\section{References}

1. Shain, A.H.; Bastian, B.C. From melanocytes to melanomas. Nat. Rev. Cancer 2016, 16, 345-358. [CrossRef] [PubMed]

2. Siegel, R.L.; Miller, K.D.; Fuchs, H.E.; Jemal, A. Cancer statistics, 2021. CA Cancer J. Clin. 2021, 71, 7-33. [CrossRef] [PubMed]

3. Cannavò, S.P.; Tonacci, A.; Bertino, L.; Casciaro, M.; Borgia, F.; Gangemi, S. The role of oxidative stress in the biology of melanoma: A systematic review. Pathol. Res. Pract. 2019, 215, 21-28. [CrossRef] [PubMed]

4. Premi, S.; Wallisch, S.; Mano, C.M.; Weiner, A.B.; Bacchiocchi, A.; Wakamatsu, K.; Bechara, E.J.H.; Halaban, R.; Douki, T.; Brash, D.E. Chemiexcitation of melanin derivatives induces DNA photoproducts long after UV exposure. Science 2015, 347, 842-847. [CrossRef]

5. Liou, G.Y.; Storz, P. Reactive oxygen species in cancer. Free Radic. Res. 2010, 44, 479-496. [CrossRef]

6. Corazao-Rozas, P.; Guerreschi, P.; Jendoubi, M.; André, F.; Jonneaux, A.; Scalbert, C.; Garçon, G.; Malet-Martino, M.; Balayssac, S.; Rocchi, S.; et al. Mitochondrial oxidative stress is the Achille's heel of melanoma cells resistant to braf-mutant inhibitor. Oncotarget 2013, 4, 1986-1998. [CrossRef]

7. Miller, A.J.; Mihm, M.C. Melanoma. N. Engl. J. Med. 2006, 355, 51-65. [CrossRef]

8. Wittgen, H.G.M.; van Kempen, L.C.L.T. Reactive oxygen species in melanoma and its therapeutic implications. Melanoma Res. 2007, 17, 400-409. [CrossRef]

9. Purohit, V.; Simeone, D.M.; Lyssiotis, C.A. Metabolic regulation of redox balance in cancer. Cancers 2019, 11, 955. [CrossRef]

10. Ferraz, L.S.; da Costa, R.T.; da Costa, C.A.; Ribeiro, C.A.J.; Arruda, D.C.; Maria-Engler, S.S.; Rodrigues, T. Targeting mitochondria in melanoma: Interplay between MAPK signaling pathway and mitochondrial dynamics. Biochem. Pharmacol. 2020, $178,114104$. [CrossRef]

11. Arslanbaeva, L.R.; Santoro, M.M. Adaptive redox homeostasis in cutaneous melanoma. Redox Biol. 2020, 37, 101753. [CrossRef] [PubMed]

12. Haq, R.; Shoag, J.; Andreu-Perez, P.; Yokoyama, S.; Edelman, H.; Rowe, G.C.; Frederick, D.T.; Hurley, A.D.; Nellore, A.; Kung, A.L.; et al. Oncogenic BRAF regulates oxidative metabolism via PGC1 $\alpha$ and MITF. Cancer Cell 2013, 23, 302-315. [CrossRef] [PubMed]

13. Khamari, R.; Trinh, A.; Gabert, P.E.; Corazao-Rozas, P.; Riveros-Cruz, S.; Balayssac, S.; Malet-Martino, M.; Dekiouk, S.; Joncquel Chevalier Curt, M.; Maboudou, P.; et al. Glucose metabolism and NRF2 coordinate the antioxidant response in melanoma resistant to MAPK inhibitors. Cell Death Dis. 2018, 9, 325. [CrossRef] [PubMed]

14. Yuan, L.; Mishra, R.; Patel, H.; Abdulsalam, S.; Greis, K.D.; Kadekaro, A.L.; Merino, E.J.; Garrett, J.T. Utilization of reactive oxygen species targeted therapy to prolong the efficacy of BRAF inhibitors in melanoma. J. Cancer 2018, 9, 4665-4676. [CrossRef]

15. Tsoi, J.; Robert, L.; Paraiso, K.; Galvan, C.; Sheu, K.M.; Lay, J.; Wong, D.J.L.; Atefi, M.; Shirazi, R.; Wang, X.; et al. Multi-stage differentiation defines melanoma subtypes with differential vulnerability to drug-induced iron-dependent oxidative stress. Cancer Cell 2018, 33, 890-904.e5. [CrossRef]

16. Bishal Paudel, B.; Lewis, J.E.; Hardeman, K.N.; Hayford, C.E.; Robbins, C.J.; Codreanu, S.G.; Sherrod, S.D.; McLean, J.A.; Kemp, M.L.; Quaranta, V. Disruption of redox balance enhances the effects of BRAF-inhibition in melanoma cells. bioRxiv 2019, 818989. [CrossRef]

17. Galadari, S.; Rahman, A.; Pallichankandy, S.; Thayyullathil, F. Reactive oxygen species and cancer paradox: To promote or to suppress? Free Radic. Biol. Med. 2017, 104, 144-164. [CrossRef]

18. Ekshyyan, O.; Aw, T.Y. Decreased susceptibility of differentiated PC12 cells to oxidative challenge: Relationship to cellular redox and expression of apoptotic protease activator factor-1. Cell Death Differ. 2005, 12, 1066-1077. [CrossRef] 
19. Liu-Smith, F.; Dellinger, R.; Meyskens, F.L. Updates of reactive oxygen species in melanoma etiology and progression. Arch. Biochem. Biophys. 2014, 563, 51-55. [CrossRef]

20. Obrador, E.; Liu-Smith, F.; Dellinger, R.W.; Salvador, R.; Meyskens, F.L.; Estrela, J.M. Oxidative stress and antioxidants in the pathophysiology of malignant melanoma. Biol. Chem. 2019, 400, 589-612. [CrossRef]

21. Brohem, C.A.; Sawada, T.C.H.; Massaro, R.R.; Almeida, R.L.; Rivelli, D.P.; Ropke, C.D.; da Silva, V.V.; de Lima, T.M.; Curi, R.; Barros, S.B.M.; et al. Apoptosis induction by 4-nerolidylcatechol in melanoma cell lines. Toxicol. Vitr. Int. J. Publ. Assoc. BIBRA 2009, 23, 111-119. [CrossRef] [PubMed]

22. Alves-Fernandes, D.K.; de Oliveira, É.A.; Faião-Flores, F.; Alicea-Rebecca, G.; Weeraratna, A.T.; Smalley, K.S.M.; de Barros, S.B.M.; Maria-Engler, S.S. ER stress promotes antitumor effects in BRAFi/MEKi resistant human melanoma induced by natural compound 4-nerolidylcathecol (4-NC). Pharmacol. Res. 2019, 141, 63-72. [CrossRef] [PubMed]

23. Obrador, E.; Salvador, R.; López-Blanch, R.; Jihad-Jebbar, A.; Alcácer, J.; Benlloch, M.; Pellicer, J.A.; Estrela, J.M. Melanoma in the liver: Oxidative stress and the mechanisms of metastatic cell survival. Semin. Cancer Biol. 2021, 71, 109-121. [CrossRef] [PubMed]

24. Scatolini, M.; Grand, M.M.; Grosso, E.; Venesio, T.; Pisacane, A.; Balsamo, A.; Sirovich, R.; Risio, M.; Chiorino, G. Altered molecular pathways in melanocytic lesions. Int. J. Cancer 2010, 126, 1869-1881. [CrossRef] [PubMed]

25. Gao, J.; Aksoy, B.A.; Dogrusoz, U.; Dresdner, G.; Gross, B.; Sumer, S.O.; Sun, Y.; Jacobsen, A.; Sinha, R.; Larsson, E.; et al Integrative analysis of complex cancer genomics and clinical profiles using the CBioPortal. Sci. Signal. 2013, 6, pl1. [CrossRef] [PubMed]

26. Cerami, E.; Gao, J.; Dogrusoz, U.; Gross, B.E.; Sumer, S.O.; Aksoy, B.A.; Jacobsen, A.; Byrne, C.J.; Heuer, M.L.; Larsson, E.; et al. The CBio cancer genomics portal: An open platform for exploring multidimensional cancer genomics data. Cancer Discov. 2012, 2, 401-404. [CrossRef]

27. Yarlagadda, K.; Hassani, J.; Foote, I.P.; Markowitz, J. The role of nitric oxide in melanoma. Biochim. Biophys. Acta. Rev. Cancer 2017, 1868, 500-509. [CrossRef]

28. Bogdan, C. Nitric oxide synthase in innate and adaptive immunity: An update. Trends Immunol. 2015, 36, 161-178. [CrossRef]

29. Nathan, C. Nitric oxide as a secretory product of mammalian cells. FASEB J. Off. Publ. Fed. Am. Soc. Exp. Biol. 1992, 6, 3051-3064. [CrossRef]

30. Bruch-Gerharz, D.; Ruzicka, T.; Kolb-Bachofen, V. Nitric oxide and its implications in skin homeostasis and disease-A review. Arch. Dermatol. Res. 1998, 290, 643-651. [CrossRef]

31. Massi, D.; Marconi, C.; Franchi, A.; Bianchini, F.; Paglierani, M.; Ketabchi, S.; Miracco, C.; Santucci, M.; Calorini, L. Arginine metabolism in tumor-associated macrophages in cutaneous malignant melanoma: Evidence from human and experimental tumors. Hum. Pathol. 2007, 38, 1516-1525. [CrossRef] [PubMed]

32. Joshi, M.; Strandhoy, J.; White, W.L. Nitric oxide synthase activity is up-regulated in melanoma cell lines. Melanoma Res. 1996, 6 , 121-126. [CrossRef] [PubMed]

33. Ahmed, B.; van den Oord, J.J. Expression of the inducible isoform of nitric oxide synthase in pigment cell lesions of the skin. Br. J. Dermatol. 2000, 142, 432-440. [CrossRef] [PubMed]

34. Grimm, E.A.; Ellerhorst, J.; Tang, C.H.; Ekmekcioglu, S. Constitutive intracellular production of INOS and NO in Human melanoma: Possible role in regulation of growth and resistance to apoptosis. Nitric Oxide Biol. Chem. 2008, 19, 133-137. [CrossRef] [PubMed]

35. Johansson, C.C.; Egyházi, S.; Masucci, G.; Harlin, H.; Mougiakakos, D.; Poschke, I.; Nilsson, B.; Garberg, L.; Tuominen, R.; Linden, D.; et al. Prognostic significance of tumor INOS and COX-2 in stage III malignant cutaneous melanoma. Cancer Immunol. Immunother. 2009, 58, 1085-1094. [CrossRef]

36. Vannini, F.; Kashfi, K.; Nath, N. The dual role of INOS in cancer. Redox Biol. 2015, 6, 334-343. [CrossRef]

37. Ekmekcioglu, S.; Ellerhorst, J.; Smid, C.M.; Prieto, V.G.; Munsell, M.; Buzaid, A.C.; Grimm, E.A. Inducible nitric oxide synthase and nitrotyrosine in human metastatic melanoma tumors correlate with poor survival. Clin. Cancer Res. Off. J. Am. Assoc. Cancer Res. 2000, 6, 4768-4775.

38. Van den Oord, A. Expression of the neuronal isoform of nitric oxide synthase (NNOS) and its inhibitor, protein inhibitor of NNOS, in pigment cell lesions of the skin. Br. J. Dermatol. 1999, 141, 12-19. [CrossRef]

39. Huang, H.; Li, H.; Yang, S.; Chreifi, G.; Martásek, P.; Roman, L.J.; Meyskens, F.L.; Poulos, T.L.; Silverman, R.B. Potent and selective double-headed-2-carboximidamide of neuronal nitric oxide synthase for the treatment of melanoma. J. Med. Chem. 2014, 57, 686. [CrossRef]

40. Yang, Z.; Misner, B.; Ji, H.; Poulos, T.L.; Silverman, R.B.; Meyskens, F.L.; Yang, S. Targeting nitric oxide signaling with NNOS inhibitors as a novel strategy for the therapy and prevention of human melanoma. Antioxid. Redox Signal. 2013, 19, 433-447. [CrossRef]

41. Weiss, L. Metastatic inefficiency. Adv. Cancer Res. 1990, 54, 159-211. [CrossRef] [PubMed]

42. Sikora, A.G.; Gelbard, A.; Davies, M.A.; Sano, D.; Ekmekcioglu, S.; Kwon, J.; Hailemichael, Y.; Jayaraman, P.; Myers, J.N.; Grimm, E.A.; et al. Targeted inhibition of inducible nitric oxide synthase inhibits growth of human melanoma in vivo and synergizes with chemotherapy. Clin. Cancer Res. 2010, 16, 1834-1844. [CrossRef] [PubMed]

43. Huang, S.-H.; Hsu, M.-H.; Hsu, S.-C.; Yang, J.-S.; Huang, W.-W.; Huang, A.-C.; Hsiao, Y.-P.; Yu, C.-C.; Chung, J.-G. Phenethyl isothiocyanate triggers apoptosis in human malignant melanoma A375.S2 cells through reactive oxygen species and the mitochondriadependent pathways. Hum. Exp. Toxicol. 2014, 33, 270-283. [CrossRef] [PubMed] 
44. Huang, Y.; Yu, P.; Li, W.; Ren, G.; Roberts, A.I.; Cao, W.; Zhang, X.; Su, J.; Chen, X.; Chen, Q.; et al. P53 regulates mesenchymal stem cell-mediated tumor suppression in a tumor microenvironment through immune modulation. Oncogene 2014, 33, 3830-3838. [CrossRef]

45. Place, A.E.; Suh, N.; Williams, C.R.; Risingsong, R.; Honda, T.; Honda, Y.; Gribble, G.W.; Leesnitzer, L.M.; Stimmel, J.B.; Willson, T.M.; et al. The novel synthetic triterpenoid, CDDO-imidazolide, inhibits inflammatory response and tumor growth in vivo. Clin. Cancer Res. Off. J. Am. Assoc. Cancer Res. 2003, 9, 2798-2806.

46. Ding, Z.; Qin, Y.; Kim, S.-H.; Grimm, E.A. Nitric oxide activates the PI3Kinase-akt pathway in human melanoma cells. Free Radic. Biol. Med. 2016, 100, S120. [CrossRef]

47. Yang, J.; Wu, L.J.; Tashiro, S.I.; Onodera, S.; Ikejima, T. Nitric oxide activated by P38 and NF-KappaB facilitates apoptosis and cell cycle arrest under oxidative stress in evodiamine-treated human melanoma A375-S2 cells. Free Radic. Res. 2008, 42, 1-11. [CrossRef]

48. Augsburger, F.; Filippova, A.; Rasti, D.; Seredenina, T.; Lam, M.; Maghzal, G.; Mahiout, Z.; Jansen-Dürr, P.; Knaus, U.G.; Doroshow, J.; et al. Pharmacological characterization of the seven human NOX isoforms and their inhibitors. Redox Biol. 2019, $26,101272$. [CrossRef]

49. Roy, K.; Wu, Y.; Meitzler, J.L.; Juhasz, A.; Liu, H.; Jiang, G.; Lu, J.; Antony, S.; Doroshow, J.H. NADPH oxidases and cancer. Clin. Sci. 2015, 128, 863-875. [CrossRef]

50. Juhasz, A.; Ge, Y.; Markel, S.; Chiu, A.; Matsumoto, L.; van Balgooy, J.; Roy, K.; Doroshow, J.H. Expression of NADPH oxidase homologues and accessory genes in human cancer cell lines, tumours and adjacent normal tissues. Free Radic. Res. 2009, 43, 523-532. [CrossRef]

51. Liu, F.; Gomez Garcia, A.M.; Meyskens, F.L. NADPH oxidase 1 overexpression enhances invasion via matrix metalloproteinase-2 and epithelial-mesenchymal transition in melanoma cells. J. Investig. Dermatol. 2012, 132, 2033-2041. [CrossRef]

52. Yamaura, M.; Mitsushita, J.; Furuta, S.; Kiniwa, Y.; Ashida, A.; Goto, Y.; Shang, W.H.; Kubodera, M.; Kato, M.; Takata, M.; et al. NADPH oxidase 4 contributes to transformation phenotype of melanoma cells by regulating $\mathrm{G}_{2}-\mathrm{M}$ cell cycle progression. Cancer Res. 2009, 69, 2647-2654. [CrossRef] [PubMed]

53. Ribeiro-Pereira, C.; Moraes, J.A.; de Jesus Souza, M.; Laurindo, F.R.; Arruda, M.A.; Barja-Fidalgo, C. Redox Modulation of FAK Controls melanoma survival-Role of NOX4. PLoS ONE 2014, 9, e99481. [CrossRef] [PubMed]

54. Antony, S.; Jiang, G.; Wu, Y.; Meitzler, J.L.; Makhlouf, H.R.; Haines, D.C.; Butcher, D.; Hoon, D.S.; Ji, J.; Zhang, Y.; et al. NADPH oxidase 5 (NOX5)-induced reactive oxygen signaling modulates normoxic HIF-1 $\alpha$ and P27 Kip1 expression in malignant melanoma and other human tumors. Mol. Carcinog. 2017, 56, 2643-2662. [CrossRef] [PubMed]

55. Beyerstedt, S.; Franco, M.; Oliveira, T.; Mendonça, G.; Alves-Fernandes, D.; Maria-Engler, S.; Machado-Neto, J.; Lopes, L. Targeting protein disulfide isomerase to overcome resistance to BRAF inhibitors in melanoma. Free Radic. Biol. Med. 2018, 128, S62. [CrossRef]

56. Prasad, R.; Kappes, J.C.; Katiyar, S.K. Inhibition of NADPH oxidase 1 activity and blocking the binding of cytosolic and membrane-bound proteins by honokiol inhibit migratory potential of melanoma cells. Oncotarget 2016, 7, 7899-7912. [CrossRef] [PubMed]

57. Zhao, Y.; Liu, J.; McMartin, K.E. Inhibition of NADPH oxidase activity promotes differentiation of B16 melanoma cells. Oncol. Rep. 2008, 19, 1225-1230. [CrossRef]

58. Zelko, I.N.; Mariani, T.J.; Folz, R.J. Superoxide dismutase multigene family: A comparison of the CuZn-SOD (SOD1), Mn-SOD (SOD2), and EC-SOD (SOD3) gene structures, evolution, and expression. Free Radic. Biol. Med. 2002, 33, 337-349. [CrossRef]

59. Kwee, J.K.; Mitidieri, E.; Affonso, O.R. Lowered superoxide dismutase in highly metastatic B16 melanoma cells. Cancer Lett. 1991, 57, 199-202. [CrossRef]

60. Church, S.L.; Grant, J.W.; Ridnour, L.A.; Oberley, L.W.; Swanson, P.E.; Meltzer, P.S.; Trent, J.M. Increased manganese superoxide dismutase expression suppresses the malignant phenotype of human melanoma cells. Proc. Natl. Acad. Sci. USA 1993, 90, 3113-3117. [CrossRef]

61. Schadendorf, D.; Zuberbier, T.; Diehl, S.; Schadendorf, C.; Czarnetzki, B.M. Serum manganese superoxide dismutase is a new tumour marker for malignant melanoma. Melanoma Res. 1995, 5, 351-353. [CrossRef] [PubMed]

62. Yuan, L.; Mishra, R.; Patel, H.; Alanazi, S.; Wei, X.; Ma, Z.; Garrett, J.T. BRAF mutant melanoma adjusts to BRAF/MEK inhibitors via dependence on increased antioxidant SOD2 and increased reactive oxygen species levels. Cancers 2020, 12, 1661. [CrossRef] [PubMed]

63. Radojičić, R.; Spasić, M.; Simić, J.; Petrović, V.M.I. Effect of bovine Cu, Zn superoxide dismutase on C3 Clone of B-16 mouse melanoma cells in the culture. J. Steroid Biochem. 1987, 28, 118. [CrossRef]

64. Radojicic, R.; Spasic, S.; Saicic, Z.; Jovanovic, T.; Simic-Krstic, J. Superoxide dismutase activity as a function of culture aging of B-16 mouse melanoma cells. J. Serb. Chem. Soc. 2004, 69, 1005-1011. [CrossRef]

65. Wheeler, M.D.; Smutney, O.M.; Samulski, R.J. Secretion of extracellular superoxide dismutase from muscle transduced with recombinant adenovirus inhibits the growth of b16 melanomas in mice. Mol. Cancer Res. MCR 2003, 1, 871-881.

66. Robbins, D.; Zhao, Y. The role of manganese superoxide dismutase in skin cancer. Enzym. Res. 2011, 2011, 409295. [CrossRef]

67. Grammatico, P.; Maresca, V.; Roccella, F.; Roccella, M.; Biondo, L.; Catricalà, C.; Picardo, M. Increased sensitivity to peroxidizing agents is correlated with an imbalance of antioxidants in normal melanocytes from melanoma patients. Exp. Dermatol. 1998, 7, 205-212. [CrossRef] 
68. Jaworska, A.; Stojcevic-Lemic, N.; Nias, A.H.W.; Sies, H. The effect of paraquat on the radiosensitivity of melanoma cells: The role of superoxide dismutase \& CATALASE. Free Radic. Res. 2009, 18, 139-145. [CrossRef]

69. Bisevac, J.P.; Djukic, M.; Stanojevic, I.; Stevanovic, I.; Mijuskovic, Z.; Djuric, A.; Gobeljic, B.; Banovic, T.; Vojvodic, D. Association between oxidative stress and melanoma progression. J. Med. Biochem. 2018, 37, 12-20. [CrossRef]

70. Bracalente, C.; Ibañez, I.L.; Berenstein, A.; Notcovich, C.; Cerda, M.B.; Klamt, F.; Chernomoretz, A.; Durán, H. Reprogramming human A375 amelanotic melanoma cells by catalase overexpression: Upregulation of Antioxidant genes correlates with regression of melanoma malignancy and with malignant progression when downregulated. Oncotarget 2016, 7, 41154-41171. [CrossRef]

71. Hyoudou, K.; Nishikawa, M.; Kobayashi, Y.; Umeyama, Y.; Yamashita, F.; Hashida, M. PEGylated catalase prevents metastatic tumor growth aggravated by tumor removal. Free Radic. Biol. Med. 2006, 41, 1449-1458. [CrossRef] [PubMed]

72. Hyoudou, K.; Nishikawa, M.; Umeyama, Y.; Kobayashi, Y.; Yamashita, F.; Hashida, M. Inhibition of metastatic tumor growth in mouse lung by repeated administration of polyethylene glycol-conjugated catalase: Quantitative analysis with firefly luciferaseexpressing melanoma cells. Clin. Cancer Res. Off. J. Am. Assoc. Cancer Res. 2004, 10, 7685-7691. [CrossRef] [PubMed]

73. Meyskens, F.L.; Farmer, P.; Fruehauf, J.P. Redox regulation in human melanocytes and melanoma. Pigment Cell Res. 2001, 14, 148-154. [CrossRef] [PubMed]

74. $\quad$ Le Gal, K.; Ibrahim, M.X.; Wiel, C.; Sayin, V.I.; Akula, M.K.; Karlsson, C.; Dalin, M.G.; Akyürek, L.M.; Lindahl, P.; Nilsson, J.; et al Antioxidants can increase melanoma metastasis in mice. Sci. Transl. Med. 2015, 7, 308re8. [CrossRef] [PubMed]

75. Carretero, J.; Obrador, E.; Anasagasti, M.J.; Martin, J.J.; Vidal-Vanaclocha, F.; Estrela, J.M. Growth-associated changes in glutathione content correlate with liver metastatic activity of B16 melanoma cells. Clin. Exp. Metastasis 1999, 17, 567-574. [CrossRef] [PubMed]

76. Piskounova, E.; Agathocleous, M.; Murphy, M.M.; Hu, Z.; Huddlestun, S.E.; Zhao, Z.; Leitch, A.M.; Johnson, T.M.; DeBerardinis, R.J.; Morrison, S.J. Oxidative stress inhibits distant metastasis by human melanoma cells. Nature 2015, 527, 186-191. [CrossRef] [PubMed]

77. Ortega, A.L.; Carretero, J.; Obrador, E.; Gambini, J.; Asensi, M.; Rodilla, V.; Estrela, J.M. Tumor cytotoxicity by endothelial cells impairment of the mitochondrial system for glutathione uptake in mouse B16 melanoma cells that survive after in vitro interaction with the hepatic sinusoidal endothelium. J. Biol. Chem. 2003, 278, 13888-13897. [CrossRef]

78. Woźniak, A.; Drewa, G.; Woźniak, B.; Schachtschabel, D.O. Activity of antioxidant enzymes and concentration of lipid peroxidation products in selected tissues of mice of different ages, both healthy and melanoma-bearing. Z. Gerontol. Geriatr. 2004, 37, 184-189. [CrossRef]

79. Bansal, A.; Celeste Simon, M. Glutathione metabolism in cancer progression and treatment resistance. J. Cell Biol. 2018, 217, 2291-2298. [CrossRef]

80. Mena, S.; Benlloch, M.; Ortega, A.; Carretero, J.; Obrador, E.; Asensi, M.; Petschen, I.; Brown, B.D.; Estrela, J.M. Bcl-2 and glutathione depletion sensitizes B16 melanoma to combination therapy and eliminates metastatic disease. Clin. Cancer Res. 2007, 13, 2658-2666. [CrossRef]

81. Conticello, C.; Martinetti, D.; Adamo, L.; Buccheri, S.; Giuffrida, R.; Parrinello, N.; Lombardo, L.; Anastasi, G.; Amato, G.; Cavalli, M.; et al. Disulfiram, an old drug with new potential therapeutic uses for human hematological malignancies. Int. J. Cancer 2012, 131, 2197-2203. [CrossRef] [PubMed]

82. O'dwyer, P.J.; Hamilton, T.C.; Young, R.C.; Lacreta, F.P.; Carp, N.; Tew, K.D.; Padavic, K.; Comis, R.L.; Ozols, R.F. Depletion of glutathione in normal and malignant human cells in vivo by buthionine sulfoximine: Clinical and biochemical results. J. Natl. Cancer Inst. 1992, 84, 264-267. [CrossRef] [PubMed]

83. Bailey, H.H.; Mulcahy, R.T.; Tutsch, K.D.; Arzoomanian, R.Z.; Alberti, D.; Tombes, M.B.; Wilding, G.; Pomplun, M.; Spriggs, D.R. Phase I clinical trial of intravenous L-buthionine sulfoximine and melphalan: An attempt at modulation of glutathione. J. Clin. Oncol. Off. J. Am. Soc. Clin. Oncol. 1994, 12, 194-205. [CrossRef] [PubMed]

84. Fruehauf, J.P.; Zonis, S.; Al-Bassam, M.; Kyshtoobayeva, A.; Dasgupta, C.; Milovanovic, T.; Parker, R.J.; Buzaid, A.C. Melanin content and downregulation of glutathione S-transferase contribute to the action of L-buthionine-S-sulfoximine on human melanoma. Chem. Biol. Interact. 1998, 111-112, 277-305. [CrossRef]

85. Rocha, C.R.R.; Kajitani, G.S.; Quinet, A.; Fortunato, R.S.; Menck, C.F.M. NRF2 and glutathione are key resistance mediators to temozolomide in glioma and melanoma cells. Oncotarget 2016, 7, 48081-48092. [CrossRef]

86. Beberok, A.; Wrześniok, D.; Szlachta, M.; Rok, J.; Rzepka, Z.; Respondek, M.; Buszman, E. Lomefloxacin induces oxidative stress and apoptosis in COLO829 melanoma cells. Int. J. Mol. Sci. 2017, 18, 2194. [CrossRef]

87. Schott, M.; de Jel, M.M.; Engelmann, J.C.; Renner, P.; Geissler, E.K.; Bosserhoff, A.K.; Kuphal, S. Selenium-binding protein 1 is down-regulated in malignant melanoma. Oncotarget 2018, 9, 10445. [CrossRef]

88. Chen, H.; Zheng, Z.; Kim, K.Y.; Jin, X.; Roh, M.R.; Jin, Z. Hypermethylation and downregulation of glutathione peroxidase 3 are related to pathogenesis of melanoma. Oncol. Rep. 2016, 36, 2737-2744. [CrossRef]

89. Yi, Z.; Jiang, L.; Zhao, L.; Zhou, M.; Ni, Y.; Yang, Y.; Yang, H.; Yang, L.; Zhang, Q.; Kuang, Y.; et al. glutathione peroxidase 3 (GPX3) suppresses the growth of melanoma cells through reactive oxygen species (ROS)-dependent stabilization of hypoxia-inducible factor 1- $\alpha$ and 2- $\alpha$. J. Cell. Biochem. 2019, 120, 19124-19136. [CrossRef]

90. Schadendorf, D.; Jurgovsky, K.; Kohlmus, C.M.; Czarnetzki, B.M. Glutathione and related enzymes in tumor progression and metastases of human melanoma. J. Investig. Dermatol. 1995, 105, 109-112. [CrossRef] 
91. Nogués, M.R.; Giralt, M.; Cervelló, I.; del Castillo, D.; Espeso, O.; Argany, N.; Aliaga, A.; Mallol, J. Parameters related to oxygen free radicals in human skin: A study comparing healthy epidermis and skin cancer tissue. J. Investig. Dermatol. 2002, 119, 645-652. [CrossRef] [PubMed]

92. Brigelius-Flohé, R.; Kipp, A. Glutathione peroxidases in different stages of carcinogenesis. Biochim. Biophys. Acta 2009, 1790, 1555-1568. [CrossRef] [PubMed]

93. Ji, Y.; Dai, F.; Yan, S.; Shi, J.Y.; Zhou, B. Identification of catechol-type diphenylbutadiene as a tyrosinase-activated pro-oxidative chemosensitizer against melanoma A375 cells via glutathione S-transferase inhibition. J. Agric. Food Chem. 2019, 67, 9060-9069. [CrossRef] [PubMed]

94. Kanetsky, P.A.; Holmes, R.; Walker, A.; Najarian, D.; Swoyer, J.; Guerry, D.; Halpern, A.; Rebbeck, T.R. Interaction of glutathione S-transferase M1 and T1 genotypes and malignant melanoma. Cancer Epidemiol. Biomark. Prev. Publ. Am. Assoc. Cancer Res. Cosponsored Am. Soc. Prev. Oncol. 2001, 10, 509-513.

95. Yura, Y.; Johnson, R.; Watanabe, Y.; Tsukahara, Y.; Ferran, B.P.; Murdoch, C.; van der Velden, J.; Bachschmid, M.M.; Heininger, Y.J.; Matsui, R. Differential regulation of ischemic limb vascularization and tumor growth by endothelial glutaredoxin-1. Free Radic. Biol. Med. 2017, 112, 38-39. [CrossRef]

96. Schallreuter, K.U.; Wood, J.M. Sensitivity and resistance in human metastatic melanoma to the new chloroethylnitrosourea anti-tumor drug fotemustine. Biochim. Biophys. Acta 1991, 1096, 277-283. [CrossRef]

97. Schallreuter, K.U.; Gleason, F.K.; Wood, J.M. The mechanism of action of the nitrosourea anti-tumor drugs on thioredoxin reductase, glutathione reductase and ribonucleotide reductase. Biochim. Biophys. Acta 1990, 1054, 14-20. [CrossRef]

98. Fruehauf, J.P. BCNU-Mediated Glutathione Depletion and Inhibition of Glutathione Reductase, Ribonucleotide Reductase, and DNA Synthesis: Novel Mechanisms of Antineoplastic Activity. Ph.D. Thesis, Rush University, College of Nursing, Chicago, IL, USA, 1996.

99. Chong, B.S.H. The Role of Glutaredoxin-1 on B16F0 Melanoma Growth and Angiogenesis in Diet-Induced Diabetic Mice. Master's Thesis, Boston University, School of Medicine, Boston, MA, USA, 2015.

100. Li, X.; Wu, J.; Zhang, X.; Chen, W. Glutathione reductase-mediated thiol oxidative stress suppresses metastasis of murine melanoma cells. Free Radic. Biol. Med. 2018, 129, 256-267. [CrossRef]

101. Lu, J.; Holmgren, A. The thioredoxin antioxidant system. Free Radic. Biol. Med. 2014, 66, 75-87. [CrossRef]

102. Jia, J.J.; Geng, W.S.; Wang, Z.Q.; Chen, L.; Zeng, X.S. The role of thioredoxin system in cancer: Strategy for cancer therapy. Cancer Chemother. Pharmacol. 2019, 84, 453-470. [CrossRef]

103. Lincoln, D.T.; Ali Emadi, E.M.; Tonissen, K.F.; Clarke, F.M. The thioredoxin-thioredoxin reductase system: Over-expression in human cancer. Anticancer Res. 2003, 23, 2425-2433. [PubMed]

104. Chakraborty, P.; Chatterjee, S.; Kesarwani, P.; Thyagarajan, K.; Iamsawat, S.; Dalheim, A.; Nguyen, H.; Selvam, S.P.; Nasarre, P.; Scurti, G.; et al. Thioredoxin-1 improves the immunometabolic phenotype of antitumor T cells. J. Biol. Chem. 2019, 294, 9198-9212. [CrossRef] [PubMed]

105. Wang, X.; Dong, H.; Li, Q.; Li, Y.; Hong, A. Thioredoxin induces tregs to generate an immunotolerant tumor microenvironment in metastatic melanoma. Oncoimmunology 2015, 4, e1027471. [CrossRef] [PubMed]

106. Cheng, G.C.; Schulze, P.C.; Lee, R.T.; Sylvan, J.; Zetter, B.R.; Huang, H. Oxidative stress and thioredoxin-interacting protein promote intravasation of melanoma cells. Exp. Cell Res. 2004, 300, 297-307. [CrossRef]

107. Song, H.; Cho, D.; Jeon, J.H.; Han, S.H.; Hur, D.Y.; Kim, Y.S.; Choi, I. Vitamin D3 up-regulating protein 1 (VDUP1) antisense DNA regulates tumorigenicity and melanogenesis of murine melanoma cells via regulating the expression of fas ligand and reactive oxygen species. Immunol. Lett. 2003, 86, 235-247. [CrossRef]

108. Goldberg, S.F.; Miele, M.E.; Hatta, N.; Takata, M.; Paquette-Straub, C.; Freedman, L.P.; Welch, D.R. Melanoma metastasis suppression by chromosome 6: Evidence for a pathway regulated by CRSP3 and TXNIP. Cancer Res. 2003, 63, 432-440.

109. Li, K.; Tang, M.; Tong, S.; Wang, C.; Sun, Q.; Lv, M.; Sun, X.; Wang, T.; Jin, S. BRAFi induced demethylation of MiR-152-5p regulates phenotype switching by targeting TXNIP in cutaneous melanoma. Apoptosis 2020, 25, 179-191. [CrossRef]

110. Cassidy, P.B.; Honeggar, M.; Poerschke, R.L.; White, K.; Florell, S.R.; Andtbacka, R.H.I.; Tross, J.; Anderson, M.; Leachman, S.A.; Moos, P.J. The role of thioredoxin reductase 1 in melanoma metabolism and metastasis. Pigment Cell Melanoma Res. 2015, 28, 685-695. [CrossRef]

111. Cassidy, P.; Kline, C.; Carpenter, E.; Laws, M.; Moos, P.; Indra, A.; Leachman, S. Thioredoxin reductase 1 knockdown disrupts pigment synthesis in melanocytes. Free Radic. Biol. Med. 2018, 128, S64. [CrossRef]

112. Zheng, X.; Chen, Y.; Bai, M.; Liu, Y.; Xu, B.; Sun, R.; Zeng, H. The antimetastatic effect and underlying mechanisms of thioredoxin reductase inhibitor ethaselen. Free Radic. Biol. Med. 2019, 131, 7-17. [CrossRef]

113. Sachweh, M.C.C.; Stafford, W.C.; Drummond, C.J.; McCarthy, A.R.; Higgins, M.; Campbell, J.; Brodin, B.; Arnér, E.S.J.; Laín, S. Redox effects and cytotoxic profiles of MJ25 and auranofin towards malignant melanoma cells. Oncotarget 2015, 6, 16488-16506. [CrossRef]

114. Cao, Z.; Lindsay, J.G.; Isaacs, N.W. Mitochondrial peroxiredoxins. Sub Cell. Biochem. 2007, 44, 295-315. [CrossRef]

115. Cox, A.G.; Winterbourn, C.C.; Hampton, M.B. Mitochondrial peroxiredoxin involvement in antioxidant defence and redox signalling. Biochem. J. 2010, 425, 313-325. [CrossRef] [PubMed]

116. Carvalho, L.A.C.; Truzzi, D.R.; Fallani, T.S.; Alves, S.V.; Toledo, J.C.; Augusto, O.; Netto, L.E.S.; Meotti, F.C. Urate hydroperoxide oxidizes human peroxiredoxin 1 and peroxiredoxin 2. J. Biol. Chem. 2017, 292, 8705-8715. [CrossRef] 
117. Winterbourn, C.C.; Hampton, M.B. Thiol chemistry and specificity in redox signaling. Free Radic. Biol. Med. 2008, 45, 549-561. [CrossRef]

118. Hampton, M.B.; Vick, K.A.; Skoko, J.J.; Neumann, C.A. Peroxiredoxin involvement in the initiation and progression of human cancer. Antioxid. Redox Signal. 2018, 28, 591-608. [CrossRef]

119. Wood, Z.A.; Poole, L.B.; Karplus, P.A. Peroxiredoxin evolution and the regulation of hydrogen peroxide signaling. Science 2003, 300, 650-653. [CrossRef]

120. Wood, Z.A.; Schröder, E.; Robin Harris, J.; Poole, L.B. Structure, mechanism and regulation of peroxiredoxins. Trends Biochem. Sci. 2003, 28, 32-40. [CrossRef]

121. Rhee, S.G. Overview on peroxiredoxin. Mol. Cells 2016, 39, 1-5. [CrossRef]

122. Peskin, A.V.; Pace, P.E.; Behring, J.B.; Paton, L.N.; Soethoudt, M.; Bachschmid, M.M.; Winterbourn, C.C. Glutathionylation of the active site cysteines of peroxiredoxin 2 and recycling by glutaredoxin. J. Biol. Chem. 2016, 291, 3053-3062. [CrossRef]

123. Jarvis, R.M.; Hughes, S.M.; Ledgerwood, E.C. Peroxiredoxin 1 functions as a signal peroxidase to receive, transduce, and transmit peroxide signals in mammalian cells. Free Radic. Biol. Med. 2012, 53, 1522-1530. [CrossRef] [PubMed]

124. Sobotta, M.C.; Liou, W.; Stöcker, S.; Talwar, D.; Oehler, M.; Ruppert, T.; Scharf, A.N.D.; Dick, T.P. Peroxiredoxin-2 and STAT3 form a redox relay for $\mathrm{H}_{2} \mathrm{O}_{2}$ signaling. Nat. Chem. Biol. 2015, 11, 64-70. [CrossRef] [PubMed]

125. Hintsala, H.R.; Soini, Y.; Haapasaari, K.M.; Karihtala, P. Dysregulation of redox-state-regulating enzymes in melanocytic skin tumours and the surrounding microenvironment. Histopathology 2015, 67, 348-357. [CrossRef] [PubMed]

126. Lee, D.J.; Kang, D.H.; Choi, M.; Choi, Y.J.; Lee, J.Y.; Park, J.H.; Park, Y.J.; Lee, K.W.; Kang, S.W. Peroxiredoxin-2 represses melanoma metastasis by increasing E-cadherin/ $\beta$-catenin complexes in adherens junctions. Cancer Res. 2013, 73, 4744-4757. [CrossRef]

127. Furuta, J.; Nobeyama, Y.; Umebayashi, Y.; Otsuka, F.; Kikuchi, K.; Ushijima, T. Silencing of peroxiredoxin 2 and aberrant methylation of 33 CpG islands in putative promoter regions in human malignant melanomas. Cancer Res. 2006, 66, 6080-6086. [CrossRef]

128. Chung, Y.M.; Yoo, Y.D.; Park, J.K.; Kim, Y.T.; Kim, H.J. Increased expression of peroxiredoxin II confers resistance to cisplatin. Anticancer Res. 2001, 21, 1129-1133.

129. Sharapov, M.G.; Novoselov, V.I. Catalytic and signaling role of peroxiredoxins in carcinogenesis. Biochem. Biokhimiia 2019, 84, 79-100. [CrossRef]

130. Schmitt, A.; Schmitz, W.; Hufnagel, A.; Schartl, M.; Meierjohann, S. Peroxiredoxin 6 triggers melanoma cell growth by increasing arachidonic acid-dependent lipid signalling. Biochem. J. 2015, 471, 267-279. [CrossRef]

131. Stone, W.L.; Krishnan, K.; Palau, V.E.; Lightner, J.W.; Brannon, M.F. AKT1 activation up regulates peroxiredoxin 1 in human melanoma cells. Free Radic. Biol. Med. 2016, 100, S130. [CrossRef]

132. Zykova, T.A.; Zhu, F.; Vakorina, T.I.; Zhang, J.; Higgins, L.A.; Urusova, D.V.; Bode, A.M.; Dong, Z. T-LAK cell-originated protein kinase (TOPK) phosphorylation of Prx1 at Ser-32 prevents UVB-induced apoptosis in RPMI7951 melanoma cells through the regulation of prx1 peroxidase activity. J. Biol. Chem. 2010, 285, 29138-29146. [CrossRef]

133. Sinha, P.; Poland, J.; Kohl, S.; Schnölzer, M.; Helmbach, H.; Hütter, G.; Lage, H.; Schadendorf, D. Study of the development of chemoresistance in melanoma cell lines using proteome analysis. Electrophoresis 2003, 24, 2386-2404. [CrossRef] [PubMed]

134. Nawarak, J.; Huang-Liu, R.; Kao, S.H.; Liao, H.H.; Sinchaikul, S.; Chen, S.T.; Cheng, S.L. Proteomics analysis of A375 human malignant melanoma cells in response to arbutin treatment. Biochim. Biophys. Acta 2009, 1794, 159-167. [CrossRef] [PubMed]

135. Ramasamy, P.; Ramasamy, P.; Ramasamy, P.; Larkin, A.M.; Larkin, A.M.; Linge, A.; Tiernan, D.; McAree, F.; Horgan, N.; Moriarty, P.; et al. PRDX3 is associated with metastasis and poor survival in uveal melanoma. J. Clin. Pathol. 2020, 73, 408-412. [CrossRef] [PubMed]

136. Laurindo, F.R.M.; Pescatore, L.A.; de Castro Fernandes, D. Protein disulfide isomerase in redox cell signaling and homeostasis. Free Radic. Biol. Med. 2012, 52, 1954-1969. [CrossRef]

137. Täger, M.; Kröning, H.; Thiel, U.; Ansorge, S. Membrane-bound proteindisulfide isomerase (PDI) is involved in regulation of surface expression of thiols and drug sensitivity of B-CLL cells. Exp. Hematol. 1997, 25, 601-607.

138. Goplen, D.; Wang, J.; Enger, P.; Tysnes, B.B.; Terzis, A.J.A.; Laerum, O.D.; Bjerkvig, R. Protein disulfide isomerase expression is related to the invasive properties of malignant glioma. Cancer Res. 2006, 66, 9895-9902. [CrossRef]

139. Gumireddy, K.; Sun, F.; Klein-Szanto, A.J.; Gibbins, J.M.; Gimotty, P.A.; Saunders, A.J.; Schultz, P.G.; Huang, Q. In vivo selection for metastasis promoting genes in the mouse. Proc. Natl. Acad. Sci. USA 2007, 104, 6696. [CrossRef]

140. Clauser, K.R.; Hall, S.C.; Smith, D.M.; Webb, J.W.; Andrews, L.E.; Tran, H.M.; Epstein, L.B.; Burlingame, A.L. Rapid mass spectrometric peptide sequencing and mass matching for characterization of human melanoma proteins isolated by twodimensional PAGE. Proc. Natl. Acad. Sci. USA 1995, 92, 5072. [CrossRef]

141. Carta, F.; Demuro, P.R.; Zanini, C.; Santona, A.; Castiglia, D.; D’Atri, S.; Ascierto, P.A.; Napolitano, M.; Cossu, A.; Tadolini, B.; et al. Analysis of candidate genes through a proteomics-based approach in primary cell lines from malignant melanomas and their metastases. Melanoma Res. 2005, 15, 235-244. [CrossRef]

142. Hill, D.S.; Lovat, P.E.; Haass, N.K. Induction of endoplasmic reticulum stress as a strategy for melanoma therapy: Is there a future? Melanoma Manag. 2014, 1, 127. [CrossRef]

143. Haefliger, S.; Klebig, C.; Schaubitzer, K.; Schardt, J.; Timchenko, N.; Mueller, B.U.; Pabst, T. Protein disulfide isomerase blocks CEBPA translation and is up-regulated during the unfolded protein response in AML. Blood 2011, 117, 5931-5940. [CrossRef] [PubMed] 
144. Lovat, P.E.; Corazzari, M.; Armstrong, J.L.; Martin, S.; Pagliarini, V.; Hill, D.; Brown, A.M.; Piacentini, M.; Birch-Machin, M.A.; Redfern, C.P.F. Increasing melanoma cell death using inhibitors of protein disulphide isomerases to abrogate survival responses to endoplasmic reticulum stress. Cancer Res. 2008, 68, 5363. [CrossRef] [PubMed]

145. Silva, Z.; Veríssimo, T.; Videira, P.A.; Novo, C. Protein disulfide isomerases: Impact of thapsigargin treatment on their expression in melanoma cell lines. Int. J. Biol. Macromol. 2015, 79, 44-48. [CrossRef] [PubMed]

146. Mitchell, M.S.; Kan-Mitchell, J.; Minev, B.; Edman, C.; Deans, R.J. A novel melanoma gene (MG50) encoding the interleukin 1 receptor antagonist and six epitopes recognized by human cytolytic T lymphocytes. Cancer Res. 2000, 60, $6448-6456$.

147. Choi, A.; Lao, R.; Ling-Fung Tang, P.; Wan, E.; Mayer, W.; Bardakjian, T.; Shaw, G.M.; Kwok, P.Y.; Schneider, A.; Slavotinek, A. Novel mutations in PXDN cause microphthalmia and anterior segment dysgenesis. Eur. J. Hum. Genet. 2015, $23,337-341$. [CrossRef]

148. Medfai, H.; Khalil, A.; Rousseau, A.; Nuyens, V.; Paumann-Page, M.; Sevcnikar, B.; Furtmüller, P.G.; Obinger, C.; Moguilevsky, N.; Peulen, O.; et al. Human peroxidasin 1 promotes angiogenesis through ERK1/2, Akt, and FAK pathways. Cardiovasc. Res. 2019, 115, 463-475. [CrossRef]

149. Jayachandran, A.; Prithviraj, P.; Lo, P.-H.; Walkiewicz, M.; Anaka, M.; Woods, B.L.; Tan, B.; Behren, A.; Cebon, J.; McKeown, S.J.; et al. Identifying and targeting determinants of melanoma cellular invasion. Oncotarget 2016, 7, 41186-41202. [CrossRef]

150. Bauer, G. Tumor cell-protective catalase as a novel target for rational therapeutic approaches based on specific intercellular ROS signaling. Anticancer Res. 2012, 32, 2599-2624.

151. Sander, C.S.; Hamm, F.; Elsner, P.; Thiele, J.J. Oxidative stress in malignant melanoma and non-melanoma skin cancer. Br. J. Dermatol. 2003, 148, 913-922. [CrossRef]

152. Morrison, B.W.; Doudican, N.A.; Patel, K.R.; Orlow, S.J. Disulfiram induces copper-dependent stimulation of reactive oxygen species and activation of the extrinsic apoptotic pathway in melanoma. Melanoma Res. 2010, 20, 11-20. [CrossRef]

153. Rahden-Staroń, I.; Grosicka-Macią,, E.; Kurpios-Piec, D.; Czeczot, H.; Grzela, T.; Szumiło, M. The effects of sodium diethyldithiocarbamate in fibroblasts V79 cells in relation to cytotoxicity, antioxidative enzymes, glutathione, and apoptosis. Arch. Toxicol. 2012, 86, 1841. [CrossRef] [PubMed]

154. Doñate, F.; Juarez, J.C.; Burnett, M.E.; Manuia, M.M.; Guan, X.; Shaw, D.E.; Smith, E.L.P.; Timucin, C.; Braunstein, M.J.; Batuman, O.A.; et al. Identification of biomarkers for the antiangiogenic and antitumour activity of the superoxide dismutase 1 (SOD1) inhibitor tetrathiomolybdate (ATN-224). Br. J. Cancer 2008, 98, 776-783. [CrossRef] [PubMed]

155. Trapp, V.; Lee, K.; Doñate, F.; Mazar, A.P.; Fruehauf, J.P. Redox-related antimelanoma activity of ATN-224. Melanoma Res. 2009, 19, 350-360. [CrossRef]

156. Ye, Q.; Zhang, Y.; Cao, Y.; Wang, X.; Guo, Y.; Chen, J.; Horn, J.; Ponomareva, L.V.; Chaiswing, L.; Shaaban, K.A.; et al. Frenolicin $\mathrm{B}$ targets peroxiredoxin 1 and glutaredoxin 3 to trigger ROS/4E-BP1-mediated antitumor effects. Cell Chem. Biol. 2019, 26, 366-377.e12. [CrossRef] [PubMed]

157. Kang, D.H.; Lee, D.J.; Lee, S.; Lee, S.Y.; Jun, Y.; Kim, Y.; Kim, Y.; Lee, J.S.; Lee, D.K.; Lee, S.; et al. Interaction of tankyrase and peroxiredoxin II is indispensable for the survival of colorectal cancer cells. Nat. Commun. 2017, 8, 40. [CrossRef] [PubMed]

158. Karala, A.R.; Ruddock, L.W. Bacitracin is not a specific inhibitor of protein disulfide isomerase. FEBS J. 2010, $277,2454-2462$. [CrossRef] [PubMed]

159. Conesa, C.M.; Ortega, V.V.; Yáñez Gascón, M.J.; Baños, M.A.; Jordana, M.C.; Benavente-García, O.; Castillo, J. Treatment of metastatic melanoma B16F10 by the flavonoids tangeretin, rutin, and diosmin. J. Agric. Food Chem. 2005, 53, 6791-6797. [CrossRef]

160. Wang, X.; Xue, G.; Song, M.; Xu, P.; Chen, D.; Yuan, C.; Lin, L.; Flaumenhaft, R.; Li, J.; Huang, M. Molecular basis of rutin inhibition of protein disulfide isomerase (PDI) by combined in silico and experimental methods. RSC Adv. 2018, 8, 18480-18491. [CrossRef]

161. Elbatreek, M.H.; Mucke, H.; Schmidt, H.H.H.W. NOX inhibitors: From bench to naxibs to bedside. Handb. Exp. Pharmacol. 2021, 264, 145-168. [CrossRef]

162. Cahlin, C.; Gelin, J.; Delbro, D.; Lönnroth, C.; Doi, C.; Lundholm, K. Effect of cyclooxygenase and nitric oxide synthase inhibitors on tumor growth in mouse tumor models with and without cancer cachexia related to prostanoids. Cancer Res. 2000, 60, 1742.

163. Jacquelot, N.; Yamazaki, T.; Roberti, M.P.; Duong, C.P.M.; Andrews, M.C.; Verlingue, L.; Ferrere, G.; Becharef, S.; Vétizou, M.; Daillère, R.; et al. Sustained type I interferon signaling as a mechanism of resistance to PD-1 blockade. Cell Res. 2019, $29,846-861$. [CrossRef] [PubMed]

164. Wu, Z.; Yao, H.; Xu, H.; Wang, Y.; Hu, W.; Lou, G.; Zhang, L.; Huang, C.; Jiang, C.; Zhou, S.; et al. Inhibition of ENOS by L-NAME resulting in rat hind limb developmental defects through PFKFB3 mediated angiogenetic pathway. Sci. Rep. 2020, 10, 16754. [CrossRef] [PubMed]

165. Chen, W.; Jiang, Z.; Lin, N.; Zheng, Z.; Chen, Z.; Zhang, X.; Guan, X. Evaluation of N-acetyl-S-(p-Chlorophenylcarbamoyl)cysteine as an irreversible inhibitor of mammalian thioredoxin reductase1. J. Enzym. Inhib. Med. Chem. 2015, 31, 229-235. [CrossRef] [PubMed]

166. Babu, R.O.; Moorkoth, D.; Azeez, S.; Eapen, S.J. Virtual screening and in vitro assay of potential drug like inhibitors from spices against glutathione-S-transferase of meloidogyne incognita. Bioinformation 2012, 8, 319-325. [CrossRef] [PubMed]

167. Luisi, G.; Mollica, A.; Carradori, S.; Lenoci, A.; de Luca, A.; Caccuri, A.M. Nitrobenzoxadiazole-based GSTP1-1 inhibitors containing the full peptidyl moiety of (pseudo)glutathione. J. Enzym. Inhib. Med. Chem. 2016, 31, 924-930. [CrossRef] [PubMed] 
168. De Luca, A.; Carpanese, D.; Rapanotti, M.C.; Suarez Viguria, T.M.; Forgione, M.A.; Rotili, D.; Fulci, C.; Iorio, E.; Quintieri, L.; Chimenti, S.; et al. The nitrobenzoxadiazole derivative MC3181 blocks melanoma invasion and metastasis. Oncotarget 2017, 8, 15520. [CrossRef] [PubMed]

169. Zhao, Y.; Seefeldt, T.; Chen, W.; Wang, X.; Matthees, D.; Hu, Y.; Guan, X. Effects of glutathione reductase inhibition on cellular thiol redox state and related systems. Arch. Biochem. Biophys. 2009, 485, 56-62. [CrossRef]

170. Chen, W.; Seefeldt, T.; Young, A.; Zhang, X.; Zhao, Y.; Ruffolo, J.; Kaushik, R.S.; Guan, X. Microtubule S-glutathionylation as a potential approach for antimitotic agents. BMC Cancer 2012, 12, 245. [CrossRef] 